JERZY MODRZEWSKI

Uniwersytet im. Adama Mickiewicza

w Poznaniu

\title{
MEANDRY POLSKIEJ ZINSTYTUCJONALIZOWANEJ SOCJOLOGII WYCHOWANIA ${ }^{1}$
}

\begin{abstract}
Modrzewski Jerzy, Meandry polskiej zinstytucjonalizowanej socjologii wychowania [Meanders of Polish Institutionalised Educational Sociology]. Studia Edukacyjne nr 35, 2015, Poznań 2015, pp. 55-83. Adam Mickiewicz University Press. ISBN 978-83-232-2904-9. ISSN 1233-6688. DOI: 10.14746/ se. 2015.35 .3

This paper shows indeed a meandering history of Polish sociology of education, consistently defined since the Polish publication by F. Znaniecki in 1928-1930 of his two-volume textbook: Sociology of Education. Now, however, and in the entire period of sociological interest in disclosing broader sociocultural issues of education (socialization) shown in the article, it is variously identified (also institutionally) and completes with organizational forms the practice in Polish academic structures of sociological science and educational sciences. The article traces its history over the past and period and at the beginning of the 21 st century.
\end{abstract}

Key word: sociology of education, educational sociology, education, socialization

Zasadniczy dylemat, jaki jawi się już u progu rozważań nad społeczną obecnością interesującej nas tutaj dyscypliny wiedzy, a dotyczy on także wielu innych dyscyplin i subdyscyplin akademickich, to niejednoznaczność kryteriów jejidentyfikacji i istoty jej a u to nomii.

${ }^{1}$ Artykuł w jego pierwotnej - zmienionej - postaci był dedykowany Panu Profesorowi dr. hab. Janowi Włodarkowi z okazji Jego wspaniałego jubileuszu, w dowód uznania dla Jego starań i osiągnięć w chronieniu oraz pomnażaniu dorobku naukowego naszego wspólnego Mistrza Profesora Stanisława Kowalskiego, jak też koleżeńskiej sympatii zrodzonej i kontynuowanej przez minione, trwające i przekraczane pospołu półwiecze. Jego pierwotna wersja została opublikowana w pracy zbiorowej pod red. J. Kaczmarka i A. Przestalskiego, Od przeszłości ku nowym horyzontom. W kręgu historii socjologii, Poznań 2013. 
W pierwszym przypadku, jak wiadomo, przywołuje się najczęściej dwa zasadnicze kryteria jej identyfikacji - wyróżnienia spośród innych subdyscyplin nauki socjologicznej jakimi są:

- specyfika jej przedmiotu, jak i

- właściwe jej cechy podmiotowego ujmowania interesującego ją przedmiotu, wyróżniające ją spośród pozasocjologicznych dyscyplin interesujących się tym samym lub podobnie operacjonalizowanym przedmiotem².

W drugim zaś przypadku nacisk kładzie się na obejmujący i towarzyszący danej dyscyplinie proces instytucjonalizacji i profesjonalizacji jej uprawiania, przede wszystkim w środowiskach i kręgach akademickich, ale i poza nimi3 .

Rozważmy te kryteria w odniesieniu do mniej lub bardziej konsekwentnie ujawnianych socjologicznych zainteresowań z jakoś pojmowanym w nich wychowaniem, przypominając i akcentując fakt, iż dylemat ten towarzyszy historii tych zainteresowań od przeszło stu lat, to znaczy od czasu powstania i okrzepnięcia socjologicznej szkoły E. Durkheima oraz zainicjowania w niej redakcji słynnych Roczników Socjologicznych (a mam tu na uwadze pierwszą 13-tomową ich edycję) i do chwili obecnej stanowi aktualne wyzwanie dla każdego, kto interesuje się jakoś rozumianą przez siebie i innych socjologią wychowania ${ }^{4}$.

2 Jedną z wielu propozycji konkretyzowania tego kryterium w odniesieniu do socjologii wychowania, relatywizowanej $\mathrm{w}$ tym przypadku do socjologii rodziny, jest studium S. Kowalskiego poświęcone wychowaniu (w rodzinie) jako im po części wspólnemu, jednak rozmaicie ujmowanemu przedmiotowi. S Kowalski, Rodzina jako przedmiot socjologii wychowania, [w:] Metodologiczne problemy badań nad rodzina, red. Z. Tyszka, Poznań 1980.

3 Współczesny obraz nauki został wyznaczony dwoma procesami, z których pierwszy określa się mianem instytucjonalizacji, drugi zaś przybiera etykietę profesjonalizacji badań naukowych (uprawiania wiedzy naukowej), co w zasadniczej mierze wyznaczyło miejsce i rolę nauki w społeczeństwach cywilizacji przemysłowej ( $w$ tzw. społeczeństwach nowoczesnych). Rzecz się niepomiernie komplikuje w tych społeczeństwach, które wchodzą lub już tkwią w cywilizacji ponowoczesnej. W kwestii instytucjonalizacji życia społecznego, pojęcia instytucji i jej społecznej funkcji patrz m.in.: E. Babbie, Istota socjologii, Warszawa 2007, s. 75-91. Natomiast, profesjonalizacja nauki to proces, dzięki któremu jej uprawianie, prowadzenie badań naukowych, tworzenie wiedzy naukowej przestaje być sprawą prywatną, indywidualną formą głoszenia prawdy, a regulowaną odnośnymi przepisami, a więc sformalizowaną i będącą pod kontrolą instytucjonalną społeczeństwa. Wówczas tworzenie środowisk naukowych oparte jest na procedurach zatrudniania, awansowania, opłacania, socjalnego ochraniania, kształtowania stosunków i kryteriów praktyki zawodowej w nauce. Patrz: S. Amsterdamski, Between History and Method, Warszawa 1983, s. 4-8.

${ }^{4}$ Wcześniejsze niż wskazane opracowanie tego zagadnienia w monografiach: H. Spencera, What Knowledge is of Most Worth z 1861 roku i Lestera Warda, Dynamic Sociology z 1883 roku, w której zawarł on wykład socjologicznej teorii wychowania w ostatniej części tej monografii pod tytułem: „Wychowanie jako zasadniczy czynnik rozwoju”. Patrz: J. Szmatka, Socjologia wychowania - zarys problematyki, Psychologia Wychowawcza, 1972, 3. 
Problem komplikuje świadomość praktyki sytuowania socjologicznie zorientowanych zainteresowań wychowaniem zarówno w kontekście samej nauki socjologicznej, określając ją niekonsekwentnie mianem: socjologii wychowania, socjologii wychowawczej względnie pedagogicznej lub socjologii ed ukacji, czyniąc przedmiotem ich zainteresowań poznawczych i proponowanych rozwiązań służących optymalizacji praktyki społecznej rozmaicie operacjonalizowany $\mathrm{w}$ nich ich przedmiot (jakoś pojęte wychowanie, edukacja, socjalizacja, akulturacja, hominizacja uczłowieczanie, personalizacja itp.), jak i w kontekstach nauki pedagogicznej, określając je, owe zainteresowania, równie niekonsekwentnie mianem pedagogiki socjologicznej, socjopedagogiki, pedagogiki społecznej, co stanowi pretekst do niekończących się dyskusji nad specyfiką socjologicznego i pedagogicznego a s pe k $\mathrm{t} u$ ujmowania owego przedmiotu ich zainteresowania 5 .

Tak więc utrwalona $\mathrm{w}$ tradycji obu makrodyscyplin akademickich praktyka wydzielania z nich pewnego zasobu wiedzy o wychowaniu i przydawania mu wskazanych wyżej określeń, identyfikujących i wyróżniających je spośród innych ich subdyscyplin, nie była w zasadzie od przeszło stu lat i nie jest jednoznacznie akceptowana, zarówno w nauce socjologicznej jak i pedagogicznej, co znajduje także swoje odzwierciedlenie w rozmaicie spełnianych intencjach ich instytucjonalizacji i zwłaszcza profesjonalizacji uprawiających je środowisk naukowców ${ }^{6}$.

To, co wydaje się na razie wspólnym rysem wydzielanych $\mathrm{w}$ obu tych tradycyjnych już makrodyscyplinach akademickich ich wskazanych wyżej subdyscyplin jest ujmowanie $\mathrm{w}$ nich różnie pojmowanego wychowania

${ }^{5}$ Problem wzajemnych odniesień nauki socjologicznej i pedagogicznej zaprzątał wielokrotnie uwagę zarówno socjologów, jak i pedagogów, skutkując np. w rodzimym dorobku publikacyjnym także rozważaniami nad socjologicznymi i pedagogicznymi zainteresowaniami wychowaniem. Patrz m.in.: A.O. Uziembło, Pedagogika społeczna i jej związek z socjologia wychowania, Studia Socjologiczne, 1966, 4; N. Chmielnicki, Elementy socjologii wychowania w pedagogice polskiej na przełomie XIX i XX wieku, Katowice 1968; S. Kowalski, Socjologia a nauki pedagogiczne, Kwartalnik Pedagogiczny, 1969 3; W. Markiewicz, Pedagogika a socjologia, Ruch Prawniczy, Ekonomiczny i Socjologiczny, 1974, 4; S. Richer, Socjologia i pedagogika - nowe kierunki badań, Kwartalnik Pedagogiczny, 1987, 4; A. Radziewicz-Winnicki (red.), Pedagogika a socjologia wychowania. Szkice socjopedagogiczne, Katowice 1989; J. Modrzewski, Pedagogika społeczna a socjologia wychowania. Dylematy integracji, [w:] Pedagogika społeczna, tradycja $i$ wspótczesne konteksty, red. W. Theiss, M. Winiarski, Warszawa 2008.

${ }^{6}$ Warto przy tej okazji wspomnieć, iż poznawcze zainteresowanie z reguły autorsko pojmowanym wychowaniem jest obecne $\mathrm{w}$ refleksji socjologicznej w każdym teoretycznym systemie socjologii od początku jej uprawiania, a ponadto pojawia się ono $\mathrm{w}$ zasadzie $\mathrm{w}$ wielu, jeśli nie wszystkich, tak zwanych socjologiach szczegółowych, począwszy od socjologii rodziny, poprzez socjologie kultury, moralności, religii, terytorialnych form skupień społecznych, a na socjologiach ciała, intymności, emocji, czy socjologii codzienności skończywszy. 
w aspekcie i kontekstach społecznych, a może lepiej powiedzieć w aspekcie i kontekstach społeczno-kulturowych, co mogło by być traktowane jako istotny argument $\mathrm{w}$ dyskusji nad ich przedmiotową identyfikacją.

Rzecz komplikuje wszakże świadomość, iż podobnie $w$ tych samych kontekstach i nierzadko identycznych aspektach rozmaicie pojmowane wychowanie pojawia się $\mathrm{w}$ przedmiocie zainteresowań innych podstawowych nauk społecznych, jakimi są np.:

- psychologia, a wśród nauk psychologicznych przede wszystkim psychologia społeczna, która nawet w ostatnim czasie uformowała cztery hybrydy wyjątkowo bliskie $\mathrm{w}$ formie i treści nauce socjologicznej (mamy tu na uwadze tak zwaną społeczną psychologię rozwoju, psychologię środowiskową, ekologiczną i międzykulturową)7;

- historia, a zwłaszcza te historie wychowania, w których stosuje się, $\mathrm{w}$ oglądzie interesującego je przedmiotu, nierzadko teorie, metodologię i terminologię zapożyczaną od socjologii8;

- antropologia kultury, która co prawda nie usankcjonowała wydzielania z niej odrębnej, zorientowanej na ten przedmiot subdyscypliny, wszakże praktykami wychowawczymi $\mathrm{w}$ potocznym ich rozumieniu i ich kulturowymi uwzorowaniami czy instytucjonalizacją interesowała się ona od zawsze, wzbogacając je o oryginalne, interesujące także socjologię, rozstrzygnięcia teoretyczne (np. antropologiczne teorie osobowości typowej - modalnej R. Lintona, czy rewolucjonizującą naszą wiedzę o mechanizmach kulturowego przekazu międzypokoleniowego rządzących tym fenomenem w skali ogólnospołecznej i historyczno-cywilizacyjnej koncepcji trzech kultur M. Mead) ${ }^{9}$.

Nie ulega wątpliwości, iż społeczny aspekt rozumienia i ujmowania istoty wychowania jest obecny także w refleksji filozoficznej, teologicznej oraz $\mathrm{w}$ wielu innych naukach normatywnych, a także we wszystkich formujących się i funkcjonujących w świadomości oraz doświadczeniu społecznym

7 Np. akademicki podręcznik psychologii wielokulturowej Boskiego. P. Boski, Kulturowe ramy zachowań społecznych. Podręcznik psychologii międzykulturowej, Warszawa 2009; P.A. Bell, Th.C. Greene, A. Baum, Psychologia środowiskowa, Gdańsk 2004, A. Bańka, Społeczna psychologia środowiska, Warszawa 2002, czy artykuł M. Lewickiej, Miasto jako przedmiot badań psychologii, [w:] Miasto jako przedmiot badań naukowych w początkach XXI wieku, red. B. Jałowiecki, Warszawa 2008.

${ }^{8} \mathrm{~Np}$. często zaliczana do dorobku socjologii oświaty (edukacji) monumentalna monografia M. Archer jest w zasadzie pracą na poły socjologiczną i historyczną. Patrz m.in.: S. Kowalski, Systemy oświatowe scentralizowane i zdecentralizowane w świetle wyników badań M.S. Archer, AUNC, Socjologia Wychowania, 1984, 145.

9 Patrz m.in.: R. Schulz (red.), Antropologiczne podstawy wychowania, Warszawa 1996; E. Nowicka, Świat człowieka świat kultury (wiele wydań), Warszawa 2009; M. Dudzikowa, M. Czerepaniak-Walczak (red.), Wychowanie. Pojęcia, procesy, konteksty. Interdyscyplinarne ujęcie, t. 1, Gdańsk 2007. 
ideologicznych interpretacjach rzeczywistości i tej doświadczanej aktualnie, i tej projektowanej. Znajdujemy go również w programach partii politycznych, deklaracjach ruchów społecznych, czy instytucji religijnych (np. w tak zwanej społecznej nauce Kościoła katolickiego).

A warto mieć tu na uwadze także zainteresowania tym aspektem i wyrazem procesów wychowawczych, które pojawiają się i są obecne w wielu poza pedagogiką naukach prakseologicznych, które nie zawsze i niechętnie godzą się oraz realizują postulat ich służebnej, wobec praktyki społecznej funkcji projektująco-prewidystycznej, między innymi spełniającej się poprzez ich udział $\mathrm{w}$ projektowaniu taktyk i strategii pomyślnego rozwiązywania s p ołecznego problemu w y chowani $a^{10}$.

W tej niezwykle rozległej i zróżnicowanej co do kontekstów uprawiania takiego czy innego rodzaju wiedzy o wychowaniu panoramie dyscyplin nauk społecznych, interesujących się jego społeczno-kulturowym wymiarem i konstruujących sobie właściwe teoretyczne wizje jego deskrypcji i eksplikacji - rozmaitej wartości poznawczej - sytuują się także dwie subdyscypliny

10 Ujmując wychowanie w kategoriach problemu społecznego, wykorzystuję tu narastający od połowy XIX wieku dorobek socjologii zwanej stosowaną, w której pojawiły się i są $\mathrm{z}$ powodzeniem rozwijane teorie oraz koncepcje tak zwanych problemów społecznych, uwzględniające ich różnorodne przejawy, strukturę i zwłaszcza dynamikę odnoszoną do wskazywanych w niej ich źródeł i uwarunkowań. Patrz m.in. R. Merton, R. Nisbet, Contemporery Social Problems, New York 1971. Porównaj także: K. Czekaj, K. Gorlach, M. Leśniak, Labirynty wspótczesnego społeczeństwa, Katowice 1998; G. Durka (red.), Wspótczesna rzeczywistość w wybranych problemach społecznych, Kraków 2010; D.S. Eitzen, Social Structure and Social Problems in America, Boston 1974; K. Frieske (red.), Socjologia problemów społecznych. Teoria a rzeczywistość, Wrocław 1987; J.M. Henslin, Social Problems, New Jersey 2003; K. Frysztacki, Socjologia problemów społecznych, Warszawa 2009; K. Frysztacki (red.), Z zagadnień socjologii stosowanej, Kraków 1996; J. Królikowska (red.), Problemy społeczne w grze politycznej, Warszawa 2006; J. Kwaśniewski (red.), Badania problemów społecznych, Warszawa 2003; J. Kwaśniewski (red.), Badania problemów społecznych, cz. 2, Warszawa 2006; L. Miś, Problemy społeczne. Teoria, metodologia, badania, Kraków 2007; J. Sztumski, Problem spoteczny jako przedmiot badań, Studia Socjologiczne, 1977, 3; L. Miś, M. Nóżka, M. Smagacz-Poziemska, Nasze problemy. Bieda i bezrobocie we wspótczesnym społeczeństwie polskim, Kraków 2011. W tym kontekście wychowanie jawi się jako żywotne zadanie społeczeństwa, jako oczekiwanie żywione i ujawniane w strukturach społecznych, np. wobec zinstytucjonalizowanych form życia społecznego, zwłaszcza przyczyniających się do stanowienia ładu społecznego, jego petryfikacji i reprodukcji w kolejnych pojawiających się na arenie życia społecznego pokoleń. Rzecz jasna, dotyczy ono społeczeństw względnie autonomicznych w stanowieniu swojej organizacji państwowej, nie ulegających nadmiernej fascynacji ideologii neoliberalnej sankcjonującej indolencję ośrodków decyzyjnych w państwie, a przyzwalających na jego demontaż, chroniących więc i pielęgnujących znamiona własnej suwerenności i kulturowej odrębności. Problem ten stanowi zasadnicze zarzewie konfliktu, jaki pojawia się na styku państw i społeczeństw kultury euroamerykańskiej i azjatyckiej; pojawia się on również w obrębie państw i społeczeństw o różnym poziomie zaawansowania w swoim rozwoju cywilizacyjnym, w swojej uległości wobec zjawisk i stanów rzeczy określanych ogólnie mianem procesu globalizacji, a faktycznie amerykanizacji. 
nauki socjologicznej, wyodrębnione $\mathrm{z}$ niej już w drugiej połowie lat 20. XX wieku, które $\mathrm{w}$ pierwszej kolejności, zwłaszcza w Stanach Zjednoczonych AP, określono mianem socjologii wychowawczej, pedagogicznej, stosowanej (educational sociology), w drugiej zaś mianem socjologii wychowania (sociology of education $)^{11}$.

Pierwsza z nich uczyniła przedmiotem swojego zainteresowania konstrukcję projektów rozwiązywania czy łagodzenia negatywnych skutków takich czy innych przejawów doświadczania przez współczesne społeczeństwa społecznego problemu wychowania, a dzisiaj powiedzielibyśmy społecznego problemu zachowania i pomnażania znamion identyfikacji kulturowej oraz doskonalenia kondycji kompetencyjnej społeczeństwa oraz jego rozlicznych kategorii i struktur, druga zaś koncentruje swoją uwagę na rozpoznawaniu, rejestrowaniu i wyjaśnianiu społecznych praktyk wychowawczych tak, jak się one pojawiają w gromadzonym przez nią doświadczeniu empirycznym tego zjawiska i procesu społeczno-kulturowego.

Obie one doświadczają ze zmiennym skutkiem i odmienną dynamiką swojej instytucjonalizacji i profesjonalizacji uprawiających je osób oraz tworzonych przez nie zespołów i środowisk, przy tym w każdej z nich ich przedmiot rozpoznawany jest i operacjonalizowany z jednej strony wyzwaniami czy potrzebami dynamicznie zmieniającej się praktyki społecznej i towarzyszących jej nacisków cywilizacyjnych, z drugiej zaś wyzwaniami czy potrzebami konstruowanych $w$ obrębie nauki socjologicznej systemów teoretycznych i przyjmowanymi w nich założeniami hipotetycznymi co do istoty rzeczywistości społecznej i metody jej poznawania ${ }^{12}$.

11 Propozycja wydzielenia spośród socjologicznych zainteresowań wychowaniem dwóch względnie okrzepłych i instytucjonalizujących się subdyscyplin znalazła zrozumienie i uzasadnienie także na gruncie europejskim w koncepcji systematyki naukowych zainteresowań wychowaniem jako faktem i zjawiskiem społecznym u Paula Fuconeta czy Aloysa Fischera na przełomie lat 20. i 30. XX wieku. Patrz m.in. S. Kowalski, Socjologia wychowania w zarysie, Warszawa 1974, r. 1, ale do chwili obecnej jest albo mało znana, albo przemilczana, albo zignorowana. Jednym $z$ wielu dowodów owej ignorancji (głównie erudycyjnej) może być podręcznik poświęcony socjologicznej interpretacji wychowania, opublikowany w 1985 roku dla studentów collegiów i uniwersytetów brytyjskich, w którym stwierdza się, iż socjologia wychowania (w oryginale - edukacji) wyłoniła się jako odrębna dyscyplina socjologii w końcu lat 50. Patrz: D. Blackledge, B. Hunt, Sociological Interpretations of Education, London-Dover-New Hampshire 1985, ignorując równie dyskusyjną kwalifikację momentu pojawienia się jej problematyki w dziełach: Willarda Wallera, The Sociology of Teaching z 1932 roku i Floriana Znanieckiego, Social Action z 1936 roku, dokonaną przez Ch. Bidwella w jego artykule: „Sociology of Education" jako monograficznym haśle pomieszczonym w Encyclopedia of Educational Research, wydanej w Londynie w 1969 roku pod red. Roberta L. Ebela. Pomijam tu prezentację innych, równie dyskusyjnych kwalifikacji tej kwestii, o których wspomina S. Kowalski w swojej Socjologii wychowania w zarysie.

12 Są to ciągle aktualne w socjologii kwestie ontologiczno-gnoseologiczne, przesądzające o jej autonomii wobec innych dyscyplin wiedzy interesujących się światem ludzkim. Patrz 
Jest przy tym oczywiste, iż jedna i druga przybierały, w dających się wyodrębnić postaciach i fazach historii ich społecznej obecności, znamiona:

- z jednej strony społeczno-kulturowych kontekstów aktualizacji tego procesu (socjologia wychowawcza, czego nietrudno dowieść na wielu przykładach, w zasadzie zawsze jest podporządkowana aksjonormatywnym podstawom ładu społecznego społeczeństwa, w którym jest ona uprawiania i się instytucjonalizuje);

- z drugiej zaś znamiona wyodrębniających się w procesie historycznego rozwoju nauki socjologicznej zasadniczych jej orientacji teoretycznometodologicznych, wśród których trzy z nich wywarły na postać budowanych $w$ niej (socjologii wychowania) koncepcji teoretycznych szczególny wpływ, a są to jak wiadomo orientacje:

1) pozytywistyczna, neopozytywistyczna - systemowa - funkcjonalnostrukturalna z jej licznymi współczesnymi odmianami socjologii scjentystycznej;

2) humanistyczna albo antypozytywistyczna, z jej rozlicznymi odmianami i kierunkami tak zwanej socjologii interpretatywnej; oraz

3) historyczno-dialektyczna, z jej wieloma współcześnie uprawianymi odmianami tak zwanej socjologii krytycznej.

Nie ulega wątpliwości, iż rozterki paradygmatyczne towarzyszące okresom stagnacji w procesie rozwoju socjologicznej dziedziny naukowej, rozmaicie ujawniane, a często także skrywane obawy, ale i nadmierna troska o eksponowanie i rozwijanie jej nomotetycznej funkcji, a zarazem dążenie do skonstruowania dzieła kompletnego w swojej deskrypcyjnej i eksplikacyjnej postaci, i doświadczanie niepowodzeń w tym względzie, które w skrajnych przypadkach skutkują wieszczeniem końca socjologii, jaką znamy i dotychczas uprawiamy, wywierają również istotny wpływ na oblicze i kondycje historycznie oraz stacjonarnie lokowanych i kreowanych socjologicznych zainteresowań wychowaniem ${ }^{13}$.

Wszystkie te problemy i wzbudzane nimi dylematy, a wskazałem tylko niektóre z nich, towarzyszą rodzimej tradycji uprawiania i instytucjonalizowania się socjologicznych zainteresowań tym fragmentem praktyki społecz-

m.in.: W. Kwaśniewicz (red.), Orientacje teoretyczne we wspótczesnej socjologii, Kraków 1990. Por. także: A. Jasińska-Kania i inni (red.), Wspótczesne teorie socjologiczne, Warszawa 2006; A. Manterys, J. Mucha (red.), Nowe perspektywy teorii socjologicznej, Kraków 2009; M. Wieviorka, Dziewięć wykładów z socjologii, Kraków 2011.

13 Porównaj m.in.: A. Niesporek, Czy koniec socjologii jaka znamy? Katowice 2007 i komentarz recenzyjny tej monografii M.M. Kurowskiego, Tożsamość socjologii, [w:] Dawne idee nowe problemy, red. P. Śpiewak, Warszawa 2010, a także: B.S. Turner (red.), The New Blackwell Companion to Social Theory, Oxford-Chichester-Malden 2009; E. Elias, Czym jest socjologia? Warszawa $2010 \mathrm{i} \mathrm{np.} \mathrm{A.} \mathrm{Touraine,} \mathrm{O} \mathrm{socjologii,} \mathrm{Warszawa} 2010$. 
nej, który umownie nazwałem wychowaniem albo społeczną praktyką wychowania, względnie społecznym problemem wychowania.

Jak już wspomniałem, problemy związane z identyfikacją dyscyplinarnie autonomizującej się wiedzy socjologicznej o wychowaniu pojawiały się już na przełomie XIX i XX wieku, w czasie postępującego procesu instytucjonalizacji nauki socjologicznej w ogóle, zarówno w europejskich, jak i amerykańskich środowiskach jej uprawiania i trudno dzisiaj jednoznacznie stwierdzić, która i jaka ich wersja stała się dominująca w owej tradycji, ciążąc na jej współczesnych odmianach i stanach, mimo niejednokrotnie czynionych $\mathrm{w}$ tym względzie prób ich (samo)określenia dokonywanych na podstawie rozmaitych przesłanek i argumentów. Ich śledzenie i partycypacja $\mathrm{w}$ formowaniu się tradycji oraz form socjologicznych zainteresowań wychowaniem samo $\mathrm{w}$ sobie może stanowić fascynujący przedmiot zainteresowania poznawczego.

W rodzimej, w znacznej mierze formowanej w poznańskim socjologicznym środowisku akademickim, tradycji kształtowania się tych zainteresowań, znaczonej osobami i dorobkiem głównie: F. Znanieckiego, J. Chałasińskiego, J. Szczepańskiego, czy S. Kowalskiego (wszyscy mają w swoich biografiach mniej lub bardziej znaczące poznańskie epizody ${ }^{14}$ ), podziela się $\mathrm{w}$ zasadzie rozstrzygnięcie definicyjne przedmiotu socjologicznych zainteresowań wychowaniem i jego socjologicznym oglądem zaproponowanym przez F. Znanieckiego (w jego dwutomowej monografii poświęconej prezentacji kompletnej autorskiej socjologicznej teorii wychowania, dopełnionej wcześniejszymi przyczynkami zawartymi w Chłopie polskim, i późniejszymi w Ludziach teraźniejszych, Social Action i Społecznej roli studenta uniwersytetu, a także w studium poświęconym Naukowej funkcji socjologii wychowania15). Propozycja Znanieckiego wydaje się dominować przynajmniej w pierwszej

${ }^{14}$ F. Znaniecki, profesor w Uniwersytecie Poznańskim w latach 1920-1939 (A. Kwilecki, B. Czarnocki (red.), The Humanistic Sociology of Florian Znaniecki Polish Period 1920-1939, Warszawa-Poznań 1989); J. Chałasiński, student tegoż Uniwersytetu, doktor i habilitant w okresie międzywojennym od 1923 do 1935 roku (Cz. Gryko, Józef Chatasiński. Socjologiczna teoria kultury, Lublin 1989; A. Kaleta (red.), Józef Chałasiński - socjolog i humanista, Torun 1984); J. Szczepański, student tegoż Uniwersytetu i asystent w Katedrze Socjologii (J. Szczepański, Dzienniki $z$ lat 1935-1945, Ustroń 2009); S. Kowalski, student tegoż Uniwersytetu przed wojną, doktorant Znanieckiego i pracownik Uniwersytetu po 1950 roku aż do emerytury (S. Kowalski, Uniwersytet Poznański okresu międzywojennego w świetle wspomnień magistranta i doktoranta, Kronika Miasta Poznania, 1990, 1, 1 i 1990, 2, 2 oraz W. Ambrozik i in. (red.), Pamięć i obecność społeczna, Poznań 1994). Patrz także: J. Włodarek, Tradycje badawcze i perspektywy rozwoju socjologii w Uniwersytecie Poznańskim, [w:] Między przeszłością a przyszłościa, red. J. Włodarek, Poznań 1998.

${ }^{15}$ F. Znaniecki, The Scientific Function of the Sociology of Education, Educational Theory, 1951, 2. 
fazie rodzimej historii socjologii wychowania, obecnej już, do czasu wybuchu II wojny światowej, w programach kursów i studiów nauczycielskich.

Do tych znaczonych niezwykłym dynamizmem rozwoju socjologicznych zainteresowań problematyką wychowania w Polsce trzeba zaliczyć niewątpliwie niektóre publikacje uczniów Znanieckiego (zwłaszcza J. Chałasińskiego ${ }^{16}$ - mam tu na uwadze również jego powojenną monografię - podręcznik: Społeczeństwo i wychowanie ${ }^{17}$ ), niektóre prace S. Bystronia - wydane w latach trzydziestych ${ }^{18}$, dwa monograficznie opracowane przez Wojciecha Gottlieba hasła do wydanej w 1933 r. Encyklopedii wychowania ${ }^{19}$, kilka prac poświęconych wybranym środowiskom wychowawczym Z. Mysłakowskiego ${ }^{20}$, studium W. Okińskiego o samokształceniu i studium poświęconemu wczesnej biograficznie fazie aktualizacji procesu wychowania J. Szczepańskiego ${ }^{21}$.

Warto jeszcze przy okazji tej pobieżnej prezentacji wspomnieć o mało znanej rozprawce P. Rybickiego poświęconej socjologii wychowania, a pomieszczonej w opublikowanej tuż po wojnie pracy zbiorowej pod tytułem: Elementy nauk pedagogicznych, w której autor również podziela w zasadzie i akceptuje tę wzbudzoną przez Znanieckiego rodzimą tradycję socjologicznego, teoretycznego oglądu wychowania. Niewątpliwie, do dorobku tak problematyzowanej i orientowanej teoretycznie socjologii wychowania trzeba też zaliczyć niezauważone dotychczas, a opublikowane partiami dopiero krótko po wojnie pionierskie studium Piotra Baścika poświęcone procesom selekcyjnym młodzieży chłopskiej na studia w UJ-cie w okresie międzywojennym ${ }^{22}$. Problematyka ta pojawi się ponownie $\mathrm{w}$ latach sześćdziesiątych w monografii G. Babińskiego ${ }^{23}$ i siedemdziesiątych w monografii J. Jerschi-

${ }^{16}$ J. Chałasiński, Wychowanie w domu obcym jako instytucja społeczna. Studium z socjologii wychowania, Poznań 1928.

17 J. Chałasiński, Społeczeństwo i wychowanie. Socjologiczne zagadnienia szkolnictwa i wychowania w społeczeństwie wspótczesnym, Warszawa 1948 i dalsze wydania.

18 Mam tu na uwadze jego: Szkołę i społeczeństwo z 1930 roku; Uspołecznienie szkoły i inne szkice z 1933 roku oraz Szkołe jako zjawisko społeczne z 19345 roku.

${ }^{19}$ W. Gottlieb, Socjologiczna teoria wychowania i Morfologia socjologiczna wychowania dzieci i młodzieży.

${ }^{20} \mathrm{~Np}$. Rodzina wiejska jako środowisko wychowawcze z 1931 roku; Wychowanie w środowisku matomiasteczkowym z 1933 roku i Państwo a wychowanie z 1935 roku.

${ }^{21}$ J. Szczepański, Przejście z rodziny do szkoty w życiorysach młodzieży, Przegląd Socjologiczny, 1935, 1-2. Systematyczną prezentację dorobku socjologiczno-wychowawczej szkoły F. Znanieckiego w okresie międzywojennym patrz: W. Wincławski, Rozwój polskiej socjologii wychowania w świetle recepcji Znanieckiego w okresie Drugiej Rzeczypospolitej, Kultura i Społeczeństwo, 1977, 3.

${ }^{22} \mathrm{Na}$ wyniki tych badań wskazujemy w artykule: J. Modrzewski i A. Zandecki, Młodzież wiejska wśród kandydatów na studia uniwersyteckie, Młodzież i Wieś, 1986, 1.

${ }^{23}$ G. Babiński, Procesy selekcji studentów w UJ w latach 1966-1972, Wrocław 1974. 
ny, poświęconej społecznej osobowości studentów UJ pochodzenia chłopskiego ${ }^{24}$ oraz w minimonografii Niny Assorodobraj, ukazującej promocyjną funkcję kursów przygotowawczych na studia w procesach selekcyjnych młodzieży w początkach drugiej połowy lat czterdziestych XX wieku25.

Ten szczególnie pomyślny dla rozwoju polskiej socjologii wychowania okres zamyka wydany tuż po wojnie i wielokrotnie wznawiany później, o czym wspomniano wyżej, podręcznik do nauki tego przedmiotu: Społeczeństwo i wychowanie J. Chałasińskiego oraz kilka studiów teoretycznych J. Szczepańskiego i S. Kowalskiego, poświęconych m.in. funkcji wychowawczej rodziny i roli środowiska w procesie formowania osobowości społecznej jednostki, opublikowanych w drugiej połowie lat czterdziestych ${ }^{26}$.

Lata późniejsze, zwłaszcza przełom lat czterdziestych i pięćdziesiątych, jak wiadomo, to okres instytucjonalnej - akademickiej hibernacji socjologii w ogóle i tym samym socjologii wychowania w szczególności, aczkolwiek i w tym okresie pojawiają się przyczynki, w których podejmowane są rozmaite cząstkowe zagadnienia tradycyjnie zaliczane do obszaru problematyki będącej przedmiotem zainteresowania socjologii wychowania, np. problematyki selekcji młodzieży wiejskiej, chłopskiej i robotniczej do szkół rozmaitych szczebli kształcenia, a zwłaszcza na studia wyższe ${ }^{27}$.

W roku 1963 swoją monografię poświęconą procesom selekcyjnym młodzieży do studiów i w ich toku publikuje J. Szczepański, wznawiając w Polsce i wzbudzając w kilku ośrodkach akademickich zainteresowanie problematyką społecznych funkcji wychowania - szeroko pojętego - ujawnianego i realizowanego $w$ aspekcie oraz $w$ kontekstach teorii socjologicznej28. Do tej inspiracji nawiąże $\mathrm{w}$ kolejnych latach $\mathrm{w}$ swojej twórczości i badaniach S. Kowalski oraz jego uczniowie przy szerokiej współpracy z licznymi reprezentantami wielu środowisk, w tym szczecińskiego, gdańskiego, zielonogórskiego, toruńskiego, katowickiego i innych ${ }^{29}$.

${ }^{24}$ J. Jerschina, Osobowość społeczna studentów Uniwersytetu Jagiellońskiego pochodzenia chtopskiego, Wrocław 1972.

${ }^{25}$ N. Assorodobraj, Kursy przygotowawcze a zagadnienie społecznej selekcji młodzieży akademickiej, Przegląd Socjologiczny, 1947, 9.

${ }^{26}$ J. Szczepański, O pojęciu środowiska, Przegląd Socjologiczny, 1946, 1-4; tam również Jego recenzja podręcznika J. Simy, Sociologie vychovy, Praga 1938; S. Kowalski, Jednostka i jej środowisko społeczne, Wiedza i Życie, 1949, 1. Porównaj również hasło: Socjologia wychowania, [w:] Encyklopedia pedagogiczna XXI wieku, t. 5, red. T. Pilch, Warszawa 2006.

27 Czynione w tym względzie przedsięwzięcia badawcze i przyczynki teoretyzujące $\mathrm{w}$ tych latach omawia w swojej monografii J. Zieliński, Młodzież chtopska na studiach, Warszawa 1982.

28 J. Szczepański, Socjologiczne zagadnienia wyższego wykształcenia, Warszawa 1963.

${ }_{29}$ Opublikowany w 1972 roku pod red. S. Kowalskiego tom XXIII Studiów Pedagogicznych, poświęcony selekcyjnym funkcjom wychowania oraz liczne artykuły, w tym zwłaszcza 
Będzie ona obecna i rozwijana, a także dokumentowana, z zachowaniem socjologicznej orientacji $\mathrm{w}$ jej ujmowaniu, znacznym materiałem empirycznym w wielu opublikowanych wówczas i później opracowaniach, wśród których niewątpliwie wskazać trzeba monografie: R. Borowicza ${ }^{30}$, M.J. Szymańskiego ${ }^{31}$, czy J. Osińskiego ${ }^{32}$.

Sam Kowalski realizuje nieco wcześniej badania terenowe nad funkcjonowaniem szkoły powszechnej w zróżnicowanych typologicznie środowiskach jej ulokowania ${ }^{33}$. Do tej problematyki nawiążą również pedagodzy społeczni z toruńskiego ośrodka akademickiego, podejmując i kontynuując wieloletnie longitudinalne badania nad miejscem i rolą szkół powszechnych, a zwłaszcza nad ich funkcjami: socjalizacyjną, edukacyjną i diagnostycznoselekcyjną wobec dzieci i młodzieży szkolnej wywodzącej się z rozmaitych typologicznie identyfikowanych i zróżnicowanych środowisk lokalnych, zwłaszcza wiejskich ${ }^{34}$.

Udokumentowaniem realizacji tych zainteresowań staną się $\mathrm{w}$ owym czasie monografie Z. Kwiecińskiego o szkole wiejskiej ${ }^{35}$ i kilka monografii W. Wincławskiego, poświęcone wychowawczemu funkcjonowaniu typowych środowisk lokalnych Polski w pierwszej połowie lat 70. XX wieku, ze szczególnym uwzględnieniem środowisk wiejskich, rozmaicie ulokowanych w typologicznie zróżnicowanych regionach Polski ${ }^{36}$.

Ta problematyka będzie później kontynuowana zarówno w ośrodku poznańskim (monografie: W. Ambrozika o środowisku wychowawczym śred-

artykuł S. Kowalskiego, Stan i potrzeby badań nad selekcjami młodzieży na studia wyższe, [w:] Rekrutacja młodzieży na studia wyższe, red. Z. Kietlińska, Warszawa 1973 i monografia T. Frąckowiaka - ucznia S. Kowalskiego, Selekcje szkolne w typowych środowiskach wychowawczych wspótczesnej Polski, Poznań 1986.

${ }^{30}$ Do problematyki selekcji nawiąże również w swoich pracach R. Borowicz, Zakres i mechanizmy selekcji w szkolnictwie. Kształtowanie się zbiorowości studentów, Warszawa 1983 oraz Nierówności społeczne w dostępie do wyksztatcenia. Casus Suwalszczyzny, Olecko 2000.

${ }^{31}$ M.J. Szymański, Środowiskowe uwarunkowania selekcji szkolnej, Warszawa 1973 i tegoż: Selekcyjne funkcje szkolnictwa a struktura spoteczna, Warszawa 1996.

32 J. Osiński, Uwarunkowania społeczno-przestrzenne selekcji młodzieży do studiów wyższych, Warszawa 1977.

33 S. Kowalski, Szkoła w środowisku, Warszawa 1969.

${ }^{34}$ R. Borowicz, Procedura badań longitudinalnych - przykład toruńskiego zespołu badawczego, [w:] Człowiek $i$ spoteczeństwo w perspektywie zmiany społecznej. Polskie i niemieckie badania podtużne (Longitudinal Study), red. E. Narkiewicz-Niedbalec i in., Zielona Góra 2003.

35 Z. Kwieciński, Funkcjonowanie szkoły w środowisku wiejskim, Warszawa 1972, tegoż: Funkcjonowanie szkoły w rejonie uprzemystawianym, Warszawa 1972, tegoż: Poziom wiedzy uczniów a środowisko szkoty, Torun 1972.

${ }^{36} \mathrm{~W}$. Wincławski, Przemiany środowiska wychowawczego wsi w rejonie uprzemystawianym. Studium porównawcze 20 wsi gromady Bielsk w powiecie płockim, Warszawa 1973, tegoż: Typowe środowiska wychowawcze wspótczesnej Polski, Warszawa 1976. 
niego miasta i patologiach wychowawczych obecnych w środowiskach wiejskich $^{37}$, S. Wawryniuka o wychowawczym funkcjonowaniu osiedli wielkomiejskich ${ }^{38}$, czy J. Modrzewskiego o środowisku społecznym młodzieży studiującej39), jak i w ośrodkach: toruńskim - liczne prace Z. Kwiecińskiego, R. Borowicza i K. Szafraniec; zielonogórskim - M. Jakowickieje, czy warszawskim - monografie K. Przecławskiego poświęcone wychowawczemu funkcjonowaniu wielkiego miasta ${ }^{41}$.

Od drugiej połowy lat 60. XX wieku zarówno socjologowie, jak i pedagodzy ujawniają znaczne zainteresowanie młodzieżą jako swoistą kategorią społeczną, a w tym głównie młodzieżą studiującą42. Zorientowaną socjologicznie monografię poświęconą studentom Warszawy przygotowuje wówczas S. Nowak (będzie ona we fragmentach opublikowana dopiero w połowie lat 80. $)^{43}$. K. Sowa we współpracy z A. Kamińskim i K.S. Kurzelą publikują raport z badań młodzieży studiującej zamieszkującej $\mathrm{w}$ akademikach ${ }^{44}$, a także monografię poświęconą młodzieży studiującej Krakowa i Katowic ${ }^{45}$. M. Gulda prezentuje wyniki badań nad uspołecznianiem się młodzieży w warunkach środowiska akademickiego Gdańska ${ }^{46}$, natomiast K. Suszek -

37 W. Ambrozik, Wychowawcze funkcjonowanie średniego miasta uprzemystowionego, Poznań 1991, tegoż: Dewiacje wychowawcze w środowisku wiejskim, Warszawa 1997.

38 S. Wawryniuk, Ksztattowanie się systemu wychowawczego w wielkomiejskim osiedlu mieszkaniowym, Poznań 1976.

39 J. Modrzewski, Środowisko społeczne młodzieży studiującej, Poznań 1989.

${ }^{40} \mathrm{M}$. Jakowicka, Uwarunkowania funkcjonowania szkót środowiskowych w średnim mieście, Zielona Góra 1979.

${ }^{41}$ K. Przecławski, Miasto i wychowanie, Warszawa 1968, tegoż: Instytucje wychowawcze w wielkim mieście. Wybrane problemy z socjologii wychowania, Warszawa 1971. Również liczne artykuły pomieszczone w Studiach Pedagogicznych w tomach: XXXII i XLVII.

${ }^{42}$ W. Markiewicz, Wspótczesna młodzież jako przedmiot badań naukowych, Poznań 1964. Będą to liczne publikacje pojawiające się $\mathrm{w}$ kilku ośrodkach akademickich, głównie jednak warszawskim i z inspiracji początkowo Międzyuczelnianego Zakładu Badań nad Szkolnictwem Wyższym, a następnie przemianowanego na Instytut Polityki Naukowej, Postępu Technicznego i Szkolnictwa Wyższego, który co roku, na przełomie lat 70. i 80., publikował tom poświęcony wyłącznie bibliografii tych publikacji. Syntezy socjologicznych zainteresowań młodzieżą w tym okresie dokona A. Kłoskowska w artykule: Socjologia młodzieży: przegląd koncepcji, Kultura i Społeczeństwo, 1987, 2.

${ }^{43}$ S. Nowak (red.), Studenci Warszawy, Warszawa 1965 (maszynopis) i następnie we fragmentach opublikowany $w$ pracy zbiorowej pod red. G. Lindberga pod tym samym tytułem w 1987 roku.

44 J. Kurzela, A. Kamiński, K.S. Sowa, Z badań nad środowiskiem domu studenckiego. Warszawa 1967.

${ }^{45}$ K.S. Sowa, Studenci Katowic i Krakowa, Warszawa 1971.

${ }^{46}$ M. Gulda, Społeczne determinanty przebiegu studiów studentów WSP w Gdańsku (maszynopis), Gdańsk 1969. 
Szczecina ${ }^{47}$. Aspiracjom kształceniowym młodzieży wiejskiej poświęcają swoje opracowania R. Dyoniziak ${ }^{48}$ i M. Łoś ${ }^{49}$.

W tym czasie pojawia się także kilka prac poświęconych zawodowi nauczycielskiemu, ujmowanemu $\mathrm{w}$ aspekcie i kontekstach socjologicznej teorii roli społecznej50.

Wszystkie one komponują się (być może w stopniu niedostatecznym i niewątpliwie nie wyczerpywały, a wskazałem tylko wybrane ich przykłady) w zmienionych po wojnie warunkach ustrojowych w socjopedagogiczną problematykę wychowania, identyfikowanego szeroko jako wszelkie przejawy społecznego wysiłku zmierzającego do uformowania i pomnożenia kondycji kompetencyjnej kolejnych, wchodzących na arenę życia społecznego i stabilizujących się egzystencjalnie pokoleń, orientowanych (lecz niekoniecznie respektujących i petryfikujących) ku istniejącemu ustrojowi politycznemu i odpowiadającemu mu ładowi społecznemu wraz z towarzyszącymi mu i utrwalanymi w świadomości, jak i pamięci społecznej realiami swoiście pojmowanej i eksponowanej kultury klasy robotniczo-chłopskiej.

Źródłem ich teoretycznej inspiracji będzie zarówno socjologia strukturalno-funkcjonalna (w kręgu S. Kowalskiego, S. Nowaka, P. Rybickiego) ${ }^{51}$, jak i materialistyczna - krytyczna (w kręgu J. Szczepańskiego, czy W. Markiewicza) ${ }^{52}$, rozwijana wówczas w Polsce w większości ośrodków socjologicznych, wśród nich także w poznańskim (L. Nowak, S. Kozyr-Kowalski) i np. toruńskim (Z. Kwieciński). Na ich marginesie kontynuowana będzie linia teoretyczna wytyczona przez Znanieckiego, aczkolwiek modyfikowana i wzbogacana dorobkiem socjologii humanistycznej drugiej połowy $X X$ wieku, głównie przez socjologów lubelskich z kręgu KUL-u ${ }^{53}$. Nieśmiałą i niekompletną próbę prezentacji, dla celów dydaktycznych, dorobku socjologii wychowania $\mathrm{w}$ tym czasie podejmie $\mathrm{w}$ nowo utworzonym wówczas Uniwersytecie Śląskim Naum Chmielnicki ${ }^{54}$.

${ }^{47}$ K. Suszek, Środowiskowe uwarunkowania procesu uspołecznienia studentów, Szczecin 1967.

48 R. Dyoniziak, Dynamika aspiracji, Warszawa 1969.

${ }^{49}$ M. Łoś, Aspiracje a środowisko, Warszawa 1972.

50 Mam tu na uwadze m.in. opracowania: A. Kwileckiego, Rola społeczna nauczyciela na Ziemiach Zachodnich, Poznań 1960; B. Bromberka, Nauczyciel w rolach społecznych, Poznań 1973; J. Woskowskiego, O pozycji społecznej nauczyciela, Łódź-Warszawa 1964 i B. Sadaja, Społeczne problemy zawodu nauczycielskiego. Nauczyciel - zawód - środowisko, Warszawa 1967.

${ }^{51}$ Np. P. Rybicki, Struktura społecznego świata, Warszawa 1976.

${ }^{5} \mathrm{~Np}$. J. Szczepańskiego, Rzecz o nauczycielach w wychowujacym społeczeństwie socjalistycznym, Warszawa 1974.

${ }^{53} \mathrm{~Np}$. w artykule J. Majki opublikowanym w 1972 r.: Wychowanie jako czynność społeczna. Analiza wedtug schematów Znanieckiego i Parsonsa, Roczniki Filozoficzne, 1972, XX, 2.

${ }^{54}$ N. Chmielnicki, Zarys socjologii wychowania, Katowice 1972. 
Pierwsza połowa lat 70. XX wieku to czas pojawiania się opracowań syntetyzujących dorobek s o c j o l o g i i w y c h o w a n i a - mam tu na uwadze podręcznik S. Kowalskiego wydany w 1974 roku i sześciokrotnie wznawiany - jak i s o c j ol o g i i w y c h ow a w c z e j, której ukoronowaniem obecności w całym ówczesnym okresie stało się zlekceważone przez ówczesne władze i zapomniane już opracowanie angażujące około dwóch tysięcy osób, pod kierunkiem J. Szczepańskiego, jakim był opublikowany w 1973 roku Raport o stanie oświaty w PRL.

Była to pierwsza i jedyna tego rodzaju monografia socjopedagogiczna w Polsce, porównywalna (a być może i doskonalsza) z raportami: E. Faure' $^{55}$ czy Botkina, Elmandriji i Malitzy ${ }^{56}$. Do tego kręgu problematyki socjologicznej - oświatowej należy zaliczyć również bogatą w dokonania publikacyjne i badawcze w omawianym okresie twórczość ucznia S. Ossowskiego - Wiesława Wiśniewskiego, wieloletniego kierownika Zakładu Socjologii Oświaty i Wychowania Instytutu Socjologii Uniwersytetu Warszawskiego ${ }^{57}$. Czas ten obfitował również w socjologiczne publikacje poświęcone intencjonalnej działalności wychowawczej w instytucji szkolnej ${ }^{58}$, w grupach rówieśniczych dzieci i młodzieży ${ }^{59}, \mathrm{w}$ rodzinach i środowiskach lokalnych ${ }^{60}$, a także zakładach pracy ${ }^{61}$.

Mając powyższe na uwadze, można zaryzykować tezę, iż lata 70. XX wieku były dla polskiej socjologii wychowania czasem szczególnego rozkwitu, głównie za przyczyną aktywności twórczej i inspiratorskiej uczniów F. Znanieckiego, w znacznej mierze jednak zdystansowanych wobec filozoficznych, kulturalistycznych podstaw jego socjologii wychowania wszakże inspirowanych zaproponowanymi przez niego zasadniczymi kręgami socjologicznej problematyki wychowania: ideą wychowującego społeczeństwa i teorią społeczno-wychowawczego procesu urabiania osób społecznych, upodmiotawiania osobowości społecznych.

55 E. Faure i in. (red.), Uczyć się aby być, Warszawa 1975.

${ }^{56} \mathrm{~J}$. Botkin, M. Elmandrija, M. Malitza, Uczyć się bez granic. Jak zewrzeć "lukę ludzkq", Warszawa 1982.

${ }^{57}$ Np. W. Wiśniewski (red.), Oświata w społecznej świadomości, Warszawa 1984.

${ }^{58}$ Np. M. Mikulski, Szkoła środowiskowa w wielkim mieście, Warszawa 1972; T. Gołaszewski, Szkoła jako system społeczny, Warszawa 1977.

${ }_{59}$ Np. B. Misztal, Grupy rówieśnicze młodzieży, Wrocław 1974; W. Jacher, Funkcje socjalizacyjne rodziny, Kwartalnik Opolski, 1977, 4.

${ }^{60} \mathrm{~Np}$. T. Kukołowicz, Rodzina w procesie uspołeczniania dziecka, Lublin 1978.

${ }^{61} \mathrm{~Np}$. T. Sosnowski, Zakład pracy jako środowisko wychowawcze, Warszawa 1975. Zagadnienie to zostało podjęte $\mathrm{w}$ latach 80. przez D. Możdżeńską-Mrozek w jej monografii: Problemy socjalizacji dorostych. Zagadnienia teoretyczne i metodologiczne, Warszawa 1989, w której jeden z rozdziałów poświęcony został zakładowi pracy jako środowisku socjalizacji dorosłych. 
Po części inspiracje te oraz ich reperkusje dla ówcześnie uprawianej socjologicznej problematyki wychowania ilustrują treści podręcznika socjologii wychowania S. Kosińskiego i J. Suprewicza z lubelskiego ośrodka akademickiego ${ }^{62}$, a dopełniał je artykuł J. Szmatki poświęcony roli wychowania w kształtowaniu struktury i dynamiki rzeczywistości społecznej63. W okresie tym opublikowano również kilka prac poświęconych ogólnym zagadnieniom socjologicznym, istotnych i po części uwzględnianych w konstruowanych wówczas socjologicznych koncepcjach wychowania64.

Warto już w tym miejscu zasygnalizować, iż lata 70. były tym okresem w rozwoju socjologicznych i nie tylko takich zainteresowań procesami społecznego rozwoju jednostki, które sukcesywnie wchłaniały i upowszechniały interdyscyplinarnie uprawianą problematykę i teorię procesów socjalizacyjnych. Na przykład, w koncepcji S. Kowalskiego były one utożsamiane z szeroko pojętą $\mathrm{w}$ nauce socjologicznej problematyką wychowania i który jako jeden z nielicznych w Polsce socjologów przyczynił się do jej upowszechnienia i zakorzenienia w twórczości wielu jego następców ${ }^{65}$.

W okresie stanu wojennego, a więc okresie przypadającym na lata 80. zainteresowanie socjologiczną problematyką wychowania bynajmniej nie słabnie. W roku 1984 J. Jerschina publikuje artykuł pod tytułem: Socjologia wychowania - historyczne korzenie, wspótczesna problematyka i perspektywa metodologiczna66; w tym samym roku W. Wincławski w V tomie Zeszytów Naukowych Uniwersytetu Toruńskiego, w serii do chwili obecnej sygnowanej tytułem: "Socjologia Wychowania” zamieszcza artykuł: U źródeł refleksji socjologicznej nad wychowaniem w Polsce; a w trzy lata później J. Włodarek w Ruchu Prawniczym, Ekonomicznym i Socjologicznym publikuje dwa ar-

62 S. Kosiński, J. Suprewicz, Wprowadzenie do socjologii wychowania, Lublin 1978.

63 J. Szmatka, Struktura rzeczywistości społecznej, rozwój spoteczny - wychowanie, Studia Socjologiczne, 1980, 4.

64 Przywołujemy tu tytułem przykładu monografię B. Misztala, Zagadnienia społecznego uczestnictwa i wspótdziałania, Warszawa 1977; J. Szmatki, Jednostka i społeczeństwo. O zależności zjawisk indywidualnych od spotecznych, Warszawa 1980 czy pod red. S. Nowaka, Wizje człowieka $i$ społeczeństwa w teoriach $i$ badaniach naukowych, Warszawa 1984.

${ }^{65}$ Między innymi: R. Miller, Socjalizacja, wychowanie, psychoterapia, Warszawa 1982; Z. Galor, Socjalizacja a klasy spoteczne - zarys problematyki (na podstawie pracy W. I. Thomasa i F. Znanieckiego, Chtop polski w Europie i Ameryce), Studia Socjologiczne, 1990, 1-2; S. Kowalik, Szkic o koncepcjach socjalizacji [w:] Edukacja wobec zmiany społecznej, red. J.J. Brzeziński, L. Witkowski, Poznań-Torun 1994; E. Mandal, R. Stefańska-Klar (red.), Wspótczesne problemy socjalizacji, Katowice 1995; R. Borowicz, Socjalizacja, [w:] Encyklopedia socjologii, red. Z. Bokszański, Warszawa 2002; J. Modrzewski, Socjalizacja i uczestnictwo społeczne, Poznań 2007; D. Sipińska, J. Modrzewski, A. Matysiak-Błaszczyk (red.), Socjalizacja w kategoriach wieku społecznego. Standaryzacja socjalizacji inkluzyjnej, t. 1, Leszno 2010, t. 2, 2011.

${ }^{66}$ Artykuł w pracy zbiorowej pod red. J. Wasilewskiego, Wybrane zagadnienia metodologiczno-teoretyczne badań socjologicznych, Kraków 1984. 
tykuły: jeden poświęcony Socjologii wychowania w systemie nauki o społeczeństwie i drugi Wychowaniu jako przedmiotowi nauk socjologicznych, przygotowując grunt pod autorską monografię poświęconą w całości historii rodzimej zinstytucjonalizowanej socjologii wychowania, opublikowanej w początkach lat 90 . ubiegłego wieku' ${ }^{67}$.

Lata 80. XX wieku do historii rodzimej socjologii wychowania wniosły więc wiele cennych inicjatyw badawczych ${ }^{68}$, a ponadto kolejne opracowania podręcznikowe socjologii wychowania: J. Woskowskiego z ośrodka łódzkiego ${ }^{69}$ i R. Toporkiewicza zorientowanego na potrzeby dydaktyczne studentów PIPS-u z warszawskiego ośrodka akademickiego ${ }^{70}$ oraz opracowanie kompendialne tekstów do nauczania socjologii wychowania pod red. Jędrzejewskiego, uzupełniające pierwszą publikację tego rodzaju tekstów w Polsce pod tytułem Socjologowie o wychowaniu, przygotowaną i opublikowaną pod red. Z. Grzelaka ${ }^{71}$.

Wcześniej ujawniane i spełniane, z powodzeniem, inicjatywy badawcze W. Wincławskiego, odkrywające, dokumentujące i porządkujące genezę oraz międzywojenną historię rodzimych zainteresowań socjologów szeroko pojętą problematyką wychowania (oświaty) 72 , w tym czasie zostają dopełnione publikacjami zrodzonymi $\mathrm{z}$ inicjatywy pedagoga społecznego, lecz z wykształcenia socjologa - ucznia Stefana Nowaka - Andrzeja Radziewicza-Winnickiego, a mianowicie: pierwszą poświęconą procesowi instytucjonalizacji socjologii wychowania w Polsce i krajach ościennych ${ }^{73}$ oraz drugą ukazującą sylwetki i dorobek teoretyczny takich socjologów wychowania, jak: B. Bernstein, P. Bourdieu, R. Collins, M. Archer, S. Kowalski, J. Szczepański i kilku innych ${ }^{74}$. To także okres, w którym polscy socjologie wychowania (J. Jerschina i A. Radziewicz-Winnicki) podejmują współpracę z socjo-

${ }^{67}$ J. Włodarek, Socjologia wychowania w Polsce, Poznań 1992.

${ }^{68} \mathrm{~Np}$. badania wieloletnie, kontynuowane do tej pory, z inicjatywy K. Hurrelmanna podjęte $\mathrm{w}$ Polsce $\mathrm{w}$ zespole kierowanym przez J. Włodarka $\mathrm{z}$ udziałem: J. Modrzewskiego, W. Ambrozika, S. Kowalika, a obecnie M. Kokocińskiego nad wczesnymi i zaawansowanymi przejawami zaburzeń procesu socjalizacji dzieci i młodzieży szkolnej zamieszkującej w zróżnicowanych typologicznie środowiskach lokalnych.

69 J. Woskowski Socjologia wychowania, Warszawa 1983.

${ }^{70}$ R. Toporkiewicz, Socjologia wychowania, Warszawa 1986.

71 Z. Grzelak, Socjologowie o wychowaniu, Warszawa 1974; S. Jędrzejewski (red.), Wybór tekstów z socjologii wychowania, Warszawa 1982.

72 W. Wincławski, U źródet refleksji socjologicznej nad wychowaniem w Polsce, AUNC, Socjologia Wychowania, 1984, V, s. 145.

${ }_{73}$ A. Radziewicz-Winnicki (red.), Pedagogika a socjologia wychowania, Katowice 1986.

74 A. Radziewicz-Winnicki (red.), Wspótcześni socjologowie o wychowaniu (zarys wybranych koncepcji), Katowice 1993. 
logami wychowania z wybranych krajów Europy, dokonując przeglądu dorobku w tej dziedzinie w krajach współpracujących ${ }^{75}$.

Lata 90. ubiegłego wieku wnoszą do dorobku interesującej nas dyscypliny kolejne publikacje podejmujące kluczowe dla przedmiotu jej zainteresowania zagadnienia, między innymi skupione na metodologii socjologicznych badań biograficznych ${ }^{76}$. Tłumaczone są także dwa podręczniki socjologii wychowania. Pierwszy, nieco wcześniej, z języka niemieckiego Artura Meiera będący ilustracją uprawiania tej subdyscypliny w kontekstach ortodoksyjnej socjologii marksistowskiej77 i drugi Roberta Meighana kontynuujący tradycje angloamerykańskiej socjologii wychowawczej (pedagogicznej) w praktyce edukacyjnej studentów college'ów i uniwersytetów brytyjskich ${ }^{78}$.

Wśród wielu z nich ukazują się wówczas studia i monografie poświęcone socjologicznym koncepcjom osobowości społecznej79, dziecięcemu wiekowi społecznemu ${ }^{80}$, młodzieży szkolnej i studiującej ${ }^{81}$ oraz samej szkole i krajowym systemom szkolnym ${ }^{82}$.

75 A. Radziewicz-Winnicki (red.), Pedagogika a socjologia; J. Jerschina - inicjator międzynarodowego seminarium Sociology of Education w Rabce, które zaowocowało powstaniem grupy badawczej skupiającej socjologów interesujących się wychowaniem z 18 krajów; B. Bromberek wraz ze swoim zespołem nawiązuje współpracę z Wiedeńskim Ośrodkiem Badań Społecznych i z przedstawicielami 8 krajów europejskich współrealizuje badania wśród młodzieży studiującej Poznania w ramach międzynarodowego projektu FORM-PROJECT w jego realizacji aktywny udział biorą m.in.: dr A. Zandecki, J. Modrzewski, B. Gołębniak i inni.

${ }_{76}$ Pod redakcją J. Włodarka i M. Ziółkowskiego ukazuje się wówczas fundamentalne dla tej problematyki dzieło: Metoda biograficzna w socjologii, Warszawa-Poznań 1990, które dopełniały także inne publikacje poświęcone tej problematyce, a wśród wielu z nich np. pod red. T. Rzepy i J. Leońskiego, O biografii i metodzie biograficznej, Poznań 1993; dopełnione w kolejnych latach monograficznym opracowaniem pod red. Kai Kaźmierskiej, Metoda biograficzna w socjologii, Kraków 2012.

77 A. Meier, Socjologia wychowania, Warszawa 1982.

${ }^{78}$ R. Meighan, Socjologia edukacji, Toruń 1993.

${ }^{79} \mathrm{~Np} .:$ A. Bartoszek, Społeczne tworzenie osobowości. Zarys socjologicznych teorii osobowości, Katowice 1994; A. Jasińska-Kania, Socjologiczna koncepcja osobowości, [w:] Socjologia ogólna. Wykłady dla studentów, red. Z. Krawczyk, W. Morawski, Warszawa 1986; I. Pańków, Społeczeństwo a osobowość, [w:] Socjologia polska, red. Z. Krawczuk, Warszawa 1990.

80 Np. B. Szacka (red.), Polska dziecięca, Warszawa 1987, ale wznowiona w 2005 roku; M. Jacyno, A. Szulżycka, Dzieciństwo. Doświadczenie bez świata, Warszawa 1999; H. Pielka (red.), Procesy socjalizacji i wychowania w rodzinie, Koszalin 1990.

${ }^{81}$ Nawiązujące do wcześniejszych publikacji B. Misztala, Grupy rówieśnicze; J. Woskowski (red.), Z socjologicznej problematyki oświaty, wychowania i młodzieży, Łódź 1981. Po części zostały one omówione w tomie XXXVIII Przeglądu Socjologicznego z 1989 roku.

82 A. Sawisz, Szkoła a system społeczny, Warszawa 1989, tejże: System oświaty jako system przemocy symbolicznej w koncepcji Pierre Bourdieu, Studia Socjologiczne, 1978, 2, tejże: Krytyka edukacji we wspótczesnej socjologii. Nurty, kontrowersje, propozycje rozwiązań, Kultura i Społeczeństwo, 1988, 1; K.M. Słomczyński, Szkoła i wyksztatceni, [w:] Socjologia. Podstawowe problemy, red. Z. Krawczyk, Warszawa 1991. Patrz także: M. Zemło, Nowa socjologia edukacji, Białystok 1996. W tak zwanym krytycznym nurcie ówcześnie uprawianej socjologii wychowania, określanej 
W połowie lat 80., jak już wspomniano wyżej, i w latach następnych interdyscyplinarny zespół skupiający pedagogów społecznych, psychologów i socjologów ${ }^{83}$ pod kierunkiem prof. dra hab. Janusza Włodarka podejmuje współpracę z ośrodkiem akademickim w Bielefeld i osobiście z prof. dr. hab. Klausem Hurrelmannem. Zespół ten skupiony w Instytucie Socjologii UAM prowadzi przez wiele lat badania sondujące kondycję socjalizacyjną młodzieży polskiej reprezentującej środowiska wiejskie, miasteczkowe i wielkomiejskie, interesując się szczególnie doświadczanymi przez nią zagrożeniami procesu jej socjalizacji i ich konsekwencjami biograficznymi. W tym czasie, z inicjatywy tego zespołu, tłumaczone są na język polski dwie szczególnie istotne dla rozwoju teorii socjalizacji monografie K. Hurrelmanna i K.J. Tillmanna ${ }^{84}$.

Pod koniec ubiegłego wieku dla potrzeb dydaktycznych jednej z powstających wówczas dynamicznie prywatnych szkół wyższych w Polsce przygotowywany jest wypis tekstów $\mathrm{z}$ dorobku polskiej socjologii wychowania ${ }^{85}$ i niezależnie od tej inicjatywy, w szkole tej został opublikowany dwutomowy podręcznik uwzględniający wybrane problemy socjologii edukacji i zachowań społecznych ${ }^{86}$.

W początkach lat 90. inicjatywę w śledzeniu postępów w rozwoju socjologicznych, a w zasadzie socjopedagogicznych zainteresowań wychowaniem (edukacją, socjalizacją) przejmują jednak pedagodzy, organizując w 1994 roku konferencje podejmujące próby oglądu dorobku w tym zakre-

\footnotetext{
już wówczas mianem socjologii edukacji, mieści się także zbiór esejów z pogranicza pedagogiki i socjologii Z. Kwiecińskiego, Socjopatologia edukacji, Warszawa 1992 (kilka późniejszych wydań). Zarówno wcześniejsze, jak i późniejsze badania oraz publikacje tego autora w znacznej mierze podejmują wątki i zagadnienia należące do przedmiotu socjologii wychowania. Dorobek ten wszakże wymaga odrębnego studyjnego opracowania, jako że sytuuje się swoją zawartością merytoryczną w przedmiocie kilku dyscyplin pedagogicznych - politologicznych, antropologicznych i niewątpliwie socjologicznych.

${ }^{83}$ Między innymi w pracach tego zespołu uczestniczyli: prof. prof.: S. Kowalik, W. Ambrozik i J. Modrzewski, w okresie późniejszym - do chwili obecnej, co wskazano wyżej - prace te kontynuuje uczeń prof. J. Włodarka - dr M. Kokociński, autor dysertacji doktorskiej: Rola grupy rówieśniczej w procesie socjalizacji młodzieży (maszynopis), Poznań 2008, wykorzystującej po części zebrany w nim materiał faktograficzny w latach poprzednich.

${ }^{84}$ K. Hurrelmann, Struktura spoteczna a rozwój osobowości, Poznań 1994 i K.J. Tillmann, Teorie socjalizacji, Warszawa 1996 (wyd. II, Warszawa 2005). W tym samym czasie S. Kowalik inspirowany koncepcją teoretyczną Hurrelmanna - publikuje artykuł pod tytułem: Szkic o koncepcjach socjalizacji, [w:] Edukacja wobec zmiany społecznej, red. J. Brzeziński, L. Witkowski, Poznań-Torun 1994, a R. Borowicz, przygotowuje hasło: „Socjalizacja” do 4 tomu Encyklopedii socjologii, Warszawa 2002.

${ }^{85}$ W. Ambrozik, J. Modrzewski (red.), Problematyka wychowania w twórczości polskich socjologów, Koszalin1998.

${ }^{86}$ R.B. Woźniak, Zarys socjologii edukacji i zachowań społecznych. Koszalin 1997.
} 
sie, jego stanu i perspektywy rozwoju. Były to konferencje zorganizowane w środowisku poznańskim: pierwsza w Kiekrzu poświęcona 100. rocznicy urodzin prof. S. Kowalskiego i zdająca niejako sprawę z kontynuacji inicjatyw badawczych i publikacyjnych uczniów Mistrza ${ }^{87}$ oraz druga zorganizowana z inicjatywy Zakładu Socjologii Edukacji Wydziału Studiów Edukacyjnych UAM i jego kierownika Z. Kwiecińskiego, w Błażejewku k. Kórnika, której celem było dokonanie przeglądu i prezentacji

(...) aktualnych problemów edukacji w Polsce, przez studia nad głównymi nurtami współczesnej socjologii edukacji, wskazania ważnych aktualnie problemów teoretycznych pogranicza socjologii edukacji, pedagogiki i psychologii społecznej88.

W tym czasie problematyka wychowania kontynuowana jest w środowiskach socjologicznych marginalnie. Usankcjonowanie bowiem radykalnej zmiany ustrojowej w Polsce, które nastąpiło z początkiem dekady lat 90., zrodziło wobec środowisk socjologicznych w Polsce kilka bardziej zasadniczych i absorbujących te środowiska wyzwań, wśród których, obok wielu innych, za najistotniejsze uznały one śledzenie i dokumentowanie owych zmian oraz sprostanie społecznemu oczekiwaniu ich wyjaśnienia i jego poszukiwanie oraz formułowanie, jak sądzimy, zaprzątało wówczas uwagę i fascynowało szczególnie te środowiska, spychając na margines kontynuację zainteresowań między innymi problematyką wychowania, edukacji, relacji pokoleniowej ${ }^{89}$.

W zasadzie w tych warunkach i w tej sytuacji postrzegano ją jako niezbyt atrakcyjną poznawczo i, co już sygnalizowano, zagrożoną cywilizacyjnie w swojej spetryfikowanej i dotychczas praktykowanej społecznie postaci ${ }^{90}$.

87 W. Ambrozik i in. (red.), Pamięć i obecność społeczna.

88 Forum Oświatowe, 1994, 1, s. 3.

${ }^{89}$ Koncentrację wysiłków w tym względzie dokumentują między innymi takie publikacje jak: H. Domański, A. Rychard (red.), Elementy nowego ładu, Warszawa 1997; J. Włodarek (red.), Między przeszłościa a przyszłościa, Poznań 1998; J. Kurczewska (red.), Zmiana społeczna. Teorie i doświadczenia polskie, Warszawa 1999; R. Suchocka (red.), Wspótczesne społeczeństwo polskie, Poznań 2002; M. Marody (red.), Zmiana czy stagnacja? Warszawa 2004; W. Wesołowski, J. Włodarek (red.), Kręgi integracji i rodzaje tożsamości. Polska, Europa, Świat, Warszawa 2005 i wiele innych, wśród których na szczególną uwagę zasługuje monografia M. Marody, Jednostka po nowoczesności. Perspektywa socjologiczna, Warszawa 2014.

90 Zagrożenia owe wyznaczają, co również znajduje swoje egzemplifikacje w twórczości m.in. także polskich socjologów (do których może trzeba także zakwalifikować Z. Baumana), $\mathrm{w}$ zasadzie dwa postępujące $\mathrm{w}$ sposób niepohamowany procesy: $\mathrm{z}$ jednej strony proces globalizacji kultury i z drugiej - indywidualizacji tożsamości osób społecznych, aczkolwiek w tym drugim przypadku podnoszone są $\mathrm{w}$ światowej literaturze socjologicznej liczne wątpliwości czy obiekcje co do jego petryfikacji w doświadczeniu pokoleniowym. Patrz m.in. M. Maffesoli, Czas plemion, Warszawa 2008, tegoż: Rytm życia, Kraków 2012; J. Urry, Socjologia mobilności, 
Owe zagrożenia sygnalizowane będą również między innymi także w publikacjach socjologów poznańskiego środowiska uniwersyteckiego ${ }^{91}$.

Kiedy w 1998 roku ukazuje się tom poświęcony socjologii w Polsce, jego redaktorzy usprawiedliwiając przed czytelnikami nieobecność w nim relacji ze stanu i dynamiki rozwoju socjologii wychowania, piszą:

(...) Najdotkliwszą chyba lukę stanowi jednak brak w książce opracowania poświęconego socjologii wychowania (i młodzieży), będącej przecież - od czasów Znanieckiego i Chałasińskiego - jedną z czołowych dziedzin badań socjologicznych w naszym kraju. Redaktorzy z żalem mogą jedynie wyznać, że ich usiłowania $\mathrm{w}$ tym zakresie nie przyniosły zadowalającego rezultatu ${ }^{92}$.

Nie roztrząsając zasadności formułowanego w cytowanej publikacji usprawiedliwienia nieobecności w nim zdania sprawy ze stanu socjologicznych zainteresowań i badań nad wychowaniem w Polsce $w$ dwóch dekadach poprzedzających edycję wspomnianego tomu, ale i w kolejnych latach, trzeba przyznać, iż problematyka wychowania (edukacji), pojmowanego szeroko jako formy praktyki społecznej w Polsce, stanowi w tym czasie przedmiot zainteresowania przede wszystkim pedagogów społecznych, pedagogów socjologizujących i ulokowanych w środowiskach oraz instytucjach ich profesjonalnej aktywności, również w nowo tworzonych z niezwykłą i dotychczas niepraktykowaną determinacją szkołach wyższych ${ }^{93}$ - uzasadniając zawartą $w$ tytule artykułu tezę o jej meandrycznej naturze, o jej uobecnianiu się zarówno $\mathrm{w}$ socjologicznych, jak i przede wszystkim pedagogicznych kontekstach ${ }^{94}$.

Warszawa 2009. Por. także: Z. Bokszański, Indywidualizm a zmiana społeczna, Warszawa 2007 czy M. Olcoń-Kubickiej, Indywidualizacja a nowe formy wspólnotowości, Warszawa 2009.

${ }^{91}$ Współczesne zagrożenia cywilizacyjne i ustrojowe stały się przedmiotem zainteresowania także socjologów poznańskich, między innymi M. Ziółkowskiego, który redaguje wówczas tom: Ludzie przełomu tysiąclecia a cywilizacja przyszłości, Poznań 2001, w którym pojawiają się teksty tak czy inaczej podejmujące problemy interesujące także socjologię wychowania (np. teksty Tittenbruna, Kowalika, Ziółkowskiego, Domańskiego); M. Golki, Poczucie zagrożeń i wyzwań cywilizacyjnych, Poznań 2000; R. Cichockiego, Podmiotowość w społeczeństwie, Poznań 2003; P. Cichockiego, Konteksty społeczeństwa ryzyka, Poznań 2005, czy monografia S. KozyrKowalskiego, Uniwersytet a rynek, Poznań 2005.

92 Z. Krawczyk, K.Z. Sowa (red.), Socjologia w Polsce, Rzeszów 1998, s. 7 i n.

Podobnym zaskoczeniem dla czytelnika polskiego, interesującego się rodzimą tradycją i dorobkiem tej dyscypliny wiedzy socjologicznej jest powierzenie jej prezentacji w nowo projektowanym na początku pierwszej dekady naszego wieku akademickim podręczniku pedagogiki, autorowi zagranicznemu - R. Moore'owi, Socjologia edukacji, [w:] Pedagogika, t. 2, red. B. Sliwerski, Gdańsk 2006.

${ }_{93}$ Patrz między innymi: I.A. Zychowicz, Studenci Koszalina - edukacja i socjalizacja, Koszalin 2014.

94 Świadczą o tym między innymi takie publikacje, jak: H. Mielicka, Socjologia wychowania, Kielce 2000; E. Hajduk, Układy społeczne - przestrzenie procesu socjalizacji, Żary 2008; D. Sipińska, J. Modrzewski, A. Matysiak-Błaszczyk (red.), Socjalizacja inkluzyjna. 
Na szczególne podkreślenie, jak i odrębne opracowanie zasługuje wieloletnia już wówczas, a kontynuowana do tej pory, niezwykle bogata w dorobek publikacyjny aktywność poznawcza i twórcza zespołu kierowanego przez prof. Z. Melosika, funkcjonującego zarówno w Uniwersytecie im. A. Mickiewicza w Poznaniu, jak i okresowo w ówczesnej poznańskiej Akademii Medycznej, a obecnego Uniwersytetu Medycznego, autora wielu prac podejmujących kluczowe dla przedmiotu socjologii wychowania i socjologii wychowawczej (edukacji) zagadnienia, inspiratora i opiekuna naukowego licznego grona Jego uczniów, uprawiających z dużym powodzeniem problematykę, którą trudno zakwalifikować do jednej dyscypliny w ogóle i jednej uprawianej $\mathrm{w}$ niej specjalizacji; są to bowiem opracowania mieszczące się na pograniczach nauki pedagogicznej (zwłaszcza porównawczej), socjologicznej, antropologicznej, jak i politologicznej, a więc uwzględniające w swojej warstwie teoretycznej inspiracje czerpane zarówno z dorobku społecznych nauk podstawowych, jak i prakseologicznych - zwłaszcza pedagogicznych i politologicznych ${ }^{95}$.

W innych środowiskach akademickich skupiających osoby profesjonalnie zajmujące się czy interesujące się uprawianiem socjologii - problematyką

Już pobieżny, dokonany we wrześniu 2014 r., przegląd umocowania instytucjonalnego owych pedagogicznych zainteresowań społecznym aspektem wychowania ujawnił, że w pięciu uniwersytetach $\mathrm{w}$ Polsce są one uprawiane $\mathrm{w}$ jednostkach organizacyjnych ulokowanych na wydziałach pedagogicznych, a mianowicie: w Uniwersytecie w Białymstoku na Wydziale Pedagogiki i Psychologii: Zakład Socjologii Edukacji; na Uniwersytecie Bydgoskim również na Wydziale Pedagogiki i Psychologii: Zakład Socjologii Wychowania i Resocjalizacji; w Uniwersytecie Katowickim, na Wydziale Pedagogiki i Psychologii: Zakład Polityki Oświatowej i Socjologii Wychowania (zlikwidowany z końcem września tego roku); w Uniwersytecie Poznańskim na Wydziale Studiów Edukacyjnych: Zakład Socjologii Edukacji i w Uniwersytecie Toruńskim na Wydziale Nauk Pedagogicznych w Katedrze Socjologii Edukacji i Pedagogiki Społecznej. Zakład Socjologii Edukacji i Polityki Oświatowej ulokowany jest także na Wydziale Nauk Pedagogicznych Dolnośląskiej Szkoły Wyższej we Wrocławiu.

W pięciu innych uczelniach są one obecne w strukturach organizacyjnych zorientowanych na uprawianie nauki socjologicznej. I tak na Uniwersytecie Jagiellońskim na Wydziale Filozoficznym: Zakład Socjologii Gospodarki, Edukacji i Metod Badań Społecznych; Lubelskim Uniwersytecie Katolickim, na Wydziale Nauk Społecznych: Katedra Socjologii Wiedzy i Edukacji; na Uniwersytecie Szczecińskim na Wydziale Humanistycznym: Zakład Socjologii Wychowania w strukturze Instytutu Socjologii, podobnie na Uniwersytecie Warszawskim na Wydziale Filozofii i Socjologii w ramach Instytutu Socjologii: Zakład Socjologii Oświaty i Wychowania oraz w Uniwersytecie Wrocławskim na Wydziale Nauk Społecznych w ramach Instytutu Socjologii: Zakład Socjologii Edukacji.

95 Jak wspomniałem wyżej, dorobek zespołu kierowanego przez prof. Z. Melosika wymaga odrębnego opracowania, stawiając przed jego potencjalnym autorem (autorami) niezwykle wysokie wymagania kompetencyjne $\mathrm{z}$ obszaru nauki antropologicznej, socjologicznej i pedagogicznej. Jest on niezwykle bogaty w dotychczasowe dokonania twórcze i niewątpliwie rokuje pomyślnie dla rozwoju zarówno nauki pedagogicznej, jak i korespondującej z nią nauki socjologicznej, zwłaszcza identyfikowanej mianem socjologii wychowawczej (edukacji). 
wychowania - socjalizacji, w ostatnich latach pojawia się raczej na marginesach opracowań i badań poświęconych: śledzeniu dynamiki zmiany struktury społecznej w Polsce96, przeobrażeń współczesnej rodziny i związków partnerskich ${ }^{97}$, kształtowania się w nich zagrożonej względnie pomyślnej egzystencjalnie sytuacji życiowej dzieci ${ }^{98}$ i młodzieży ${ }^{99}$ sekularyzacji i popkulturalizacji obyczajowości ${ }^{100,}$ zwłaszcza wzorującej preferowany przez młodzież styl życia101, doświadczane przez nią lęki egzystencjalne102, a zwłaszcza zagrożenia zdrowotne ${ }^{103}$, obyczajowe ${ }^{104}$ itp.

96 Np. M. Marody, A. Giza-Poleszczuk, Przemiany więzi społecznych. Zarys teorii zmiany społecznej, Warszawa 2004 - zwłaszcza r. 3; T. Gmerek (red.), Edukacja i stratyfikacja społeczna, Poznań 2003; Artykuły Z. Sawińskiego i H. Domańskiego pomieszczone w pracy zbiorowej pod red. H. Domańskiego, Zmiany stratyfikacji społecznej w Polsce, Warszawa 2008; P. Żuk, O nierównościach edukacyjnych w Polsce, [w:] Podziaty klasowe i nierówności społeczne, red. P. Żuk, Warszawa 2010.

${ }^{77} \mathrm{~Np}$. M. Sikorska, Nowa matka, nowy ojciec, nowe dziecko. O nowym układzie sit w polskich rodzinach, Warszawa 2009; T. Szlendak, Socjologia rodziny. Ewolucja, historia, zróżnicowanie, Warszawa 2010.

98 Są to głównie monografie referujące wyniki badań terenowych, inicjowanych w zakładach i katedrach pedagogiki społecznej. Np.: A. Roter, Proces socjalizacji dzieci w warunkach ubóstwa społecznego, Katowice 2005; G. Cęcelek, Sytuacja szkolna dziecka z rodziny ubogiej, Warszawa 2011; K. Segiet, Dziecko i jego dzieciństwo w perspektywie naukowego poznania i doświadczania rzeczywistości, Poznań 2011; B. Smolińska-Theiss, Dzieciństwo jako status społeczny. Edukacyjne przywileje dzieci klasy średniej, Warszawa 2014.

${ }_{99} \mathrm{~Np}$. W. Kubiak-Krzywicka, Interakcyjno-kontekstualny model zaburzonej socjalizacji, Poznań-Kalisz 2010; M. Dąbrowska-Bąk, K. Pawełek, Dysfunkcjonalność lokalnego społeczeństwa wychowującego, Poznań 2013, czy K. Ferenz i K. Zajdel, Dorastanie w małych miastach, Wrocław 2012.

100 Np.: B. Łaciak, Obyczajowość polska czasu transformacji, Warszawa 2005; J. Gajda, Antropologia kulturowa. Kultura obyczajowa początku XXI wieku, Kraków 2008; B. Łaciak (red.), Obyczajowość polska początku XXI wieku - w procesie przemian, Warszawa 2014; J. Zalewska, M. CobelTokarska (red.), Od obyczaju do mody. Przemiany życia codziennego, Warszawa 2014.

101 Młodzież ostatnich dwóch dekad stanowi przedmiot żywego zainteresowania jak zwykle przede wszystkim pedagogów, ale znaczny udział w ukazaniu jej kulturowej i podmiotowej kondycji, a zwłaszcza postaci jej społecznej obecności mają również socjologowie, antropolodzy kultury, jak i psychologowie, dokumentując to zainteresowanie np. takimi publikacjami jak np.: R. Leppert, Z. Melosik, B. Wojtasik (red.), Młodzież wobec niegościnnej przyszłości, Wrocław 2005; Z. Melosik, Kultura popularna i tożsamość młodzieży, Kraków 2013; H. KrauseSikorska, M. Klichowski, Świat digital natives. Młodzież w poszukiwaniu siebie i innych, Poznań 2013.

102 Patrz między innymi: M. Kwiecińska-Zdrenka, Aktywni czy bezradni wobec własnej przyszłości? Toruń 2004; K. Szafraniec (red.), Młodzi 2011, Warszawa 2011.

103 Np.: Z. Melosik (red.), Młodzież, styl życia i zdrowie. Konteksty i kontrowersje, Poznań 2001; J.A. Malinowski, A. Zandecki (red.), Środowisko, młodzież, zdrowie, Toruń 2007.

104 Np.: J. Kurzępa, Młodzież pogranicza „świnki”, czyli o prostytucji nieletnich, Kraków 2001, tegoż: Zagrożona niewinność, Kraków 2007, tegoż: Młodzi, piękne i niedrodzy. Młodość w objęciach seksbiznesu, Kraków 2012; G.E. Kwiatkowska, I. Siudem (red.), Zachowania ryzykowne, Lublin 2012. 
W parze $\mathrm{z}$ realizowanymi w kraju badaniami terenowymi kontynuowane są także nieliczne próby teoretyzowania lokującego socjologiczną problematykę wychowania, a raczej socjalizacji w centrum lub na marginesach rozważanego w nich zagadnienia, np. dynamiki struktury społecznej105.

Współczesne socjologiczne zainteresowania szeroko pojętą problematyką wychowania nie komponują się zatem w wyraźnie wyodrębniającą się i instytucjonalizującą subdyscyplinę - a jeśli powstają przy okazji ich poznawczej realizacji socjologiczne opracowania tej problematyki, to przybierają one zwykle postać przyczynków sygnalizujących zaledwie problem, relacjonujących wyniki incydentalnych badań bądź ukazujących modne perspektywy teoretyczne ujmowania obecnego od zawsze $\mathrm{w}$ refleksji socjologicznej zagadnienia i fenomenu życia społecznego - określanego enigmatycznie i niekonsekwentnie mianem wychowania i coraz częściej socjalizacji, a skrywanego także w pojęciu - edukacji106.

Socjologia wychowania jeśli ma być kontynuowana i rozwijana w rodzimych środowiskach oraz instytucjach akademickich jako względnie zautonomizowana subdyscyplina socjologii ogólnej, a o zasadności tego przedsięwzięcia nie wątpię, gwałtownie potrzebuje mocnego impulsu $\mathrm{w}$ postaci monografii syntezującej jej dotychczasowy dorobek i prezentującej program wskazujący pola oraz kierunki jej dalszego, pomyślnego i potrzebnego rozwoju.

\section{BIBLIOGRAFIA}

Ambrozik W., Dewiacje wychowawcze w środowisku wiejskim, Warszawa 1997.

Ambrozik W., Modrzewski J. (red.), Problematyka wychowania w twórczości polskich socjologów, Koszalin 1998.

Ambrozik W., Wychowawcze funkcjonowanie średniego miasta uprzemystowionego, Poznań 1991.

Amsterdamski S., Between History and Method, Warszawa 1983.

Assorodobraj N., Kursy przygotowawcze a zagadnienie społecznej selekcji młodzieży akademickiej, Przegląd Socjologiczny, 1947, 9.

Babbie E., Istota socjologii, Warszawa 2007.

Babiński G., Procesy selekcji studentów w UJ w latach 1966-1972, Wrocław 1974.

Bańka A., Społeczna psychologia środowiska, Warszawa 2002.

Bartoszek A., Społeczne tworzenie osobowości. Zarys socjologicznych teorii osobowości, Katowice 1994.

105 Np. M. Marody, Formatowanie społeczeństwa - o starych i nowych sposobach uspołeczniania dziatań, [w:] Co dzieje się ze społeczeństwem, red. M. Flis, K. Frysztacki, G. Skąpska, P. Polak, Kraków 2011, tejże: Jednostka po nowoczesności.

106 Jak np. we wskazanej wyżej próbie podręcznikowej M.J. Szymańskiego. 
Bell P.A., Greene Th.C., Baum A., Psychologia środowiskowa, Gdańsk 2004.

Bokszański Z., Indywidualizm a zmiana społeczna, Warszawa 2007.

Borowicz R., Zakres i mechanizmy selekcji w szkolnictwie. Ksztattowanie się zbiorowości studentów, Warszawa 1983.

Borowicz R., Nierówności społeczne w dostępie do wykształcenia. Casus Suwalszczyzny, Olecko 2000.

Borowicz R., Socjalizacja, [w:] Encyklopedia socjologii, red. Z. Bokszański i inni, Warszawa 2002.

Borowicz R., Procedura badań longitudinalnych - przykład toruńskiego zespotu badawczego, [w:] red. E. Narkiewicz-Niedbalec i inni, Człowiek $i$ społeczeństwo w perspektywie zmiany społecznej. Polskie i niemieckie badania podtużne (Longitudinal Study), Zielona Góra 2003.

Boski P., Kulturowe ramy zachowań społecznych. Podręcznik psychologii międzykulturowej, Warszawa 2009.

Botkin J., Elmandrija M., Malitza M., Uczyć się bez granic. Jak zewrzeć „lukę ludzką", Warszawa 1982.

Bromberek B., Nauczyciel w rolach społecznych, Poznań 1973.

Cęcelek G., Sytuacja szkolna dziecka z rodziny ubogiej, Warszawa 2011.

Chałasiński J., Społeczeństwo $i$ wychowanie. Socjologiczne zagadnienia szkolnictwa $i$ wychowania w społeczeństwie wspótczesnym, Warszawa 1948.

Chałasiński J., Wychowanie w domu obcym jako instytucja społeczna. Studium z socjologii wychowania, Poznań 1928.

Chmielnicki N., Elementy socjologii wychowania w pedagogice polskiej na przełomie XIX i XX wieku, Katowice 1968.

Chmielnicki N., Zarys socjologii wychowania, Katowice 1972.

Cichocki P., Konteksty społeczeństwa ryzyka, Poznań 2005.

Cichocki P., Podmiotowość w społeczeństwie, Poznań 2003.

Czekaj K., Gorlach K., Leśniak M., Labirynty wspótczesnego społeczeństwa, Katowice 1998.

D. Blackledge, B. Hunt, Sociological Interpretations of Education, London-Dover-New Hampshire 1985.

Dąbrowska-Bąk M., Pawełek K., Dysfunkcjonalność lokalnego społeczeństwa wychowującego, Poznań 2013.

Domański H., Rychard A. (red.), Elementy nowego ładu, Warszawa 1997.

Domański H., Zmiany stratyfikacji społecznej w Polsce, Warszawa 2008.

Dudzikowa M., Czerepaniak-Walczak M. (red.), Wychowanie. Pojęcia, procesy, konteksty. Interdyscyplinarne ujęcie, t. 1, Gdańsk 2007.

Durka G. (red.), Wspótczesna rzeczywistość w wybranych problemach społecznych, Kraków 2010.

Dyoniziak R., Dynamika aspiracji, Warszawa 1969.

Eitzen D.S., Social Structure and Social Problems in America, Boston 1974.

Elias E., Czym jest socjologia? Warszawa 2010.

Faure E. i in. (red.), Uczyć się aby być, Warszawa 1975.

Ferenz K., Zajdel K., Dorastanie w matych miastach, Wrocław 2012.

Frąckowiak T., Selekcje szkolne w typowych środowiskach wychowawczych wspótczesnej Polski, Poznań 1986.

Frieske K. (red.), Socjologia problemów społecznych. Teoria a rzeczywistość, Wrocław 1987.

Frysztacki K. (red.), Z zagadnień socjologii stosowanej, Kraków 1996.

Frysztacki K., Socjologia problemów społecznych, Warszawa 2009. 
Gajda J., Antropologia kulturowa. Kultura obyczajowa początku XXI wieku, Kraków 2008.

Galor Z., Socjalizacja a klasy społeczne - zarys problematyki (na podstawie pracy W.I. Thomasa i F. Znanieckiego, Chłop polski w Europie i Ameryce), Studia Socjologiczne, 1990, 1-2.

Gmerek T. (red.), Edukacja i stratyfikacja społeczna, Poznań 2003.

Golka M., Poczucie zagrożeń i wyzwań cywilizacyjnych, Poznań 2000.

Gołaszewski T., Szkoła jako system społeczny, Warszawa 1977.

Gryko Cz., Józef Chatasiński. Socjologiczna teoria kultury, Lublin 1989.

Grzelak Z., Socjologowie o wychowaniu, Warszawa 1974.

Gulda M., Społeczne determinanty przebiegu studiów studentów WSP w Gdańsku (maszynopis), Gdańsk 1969.

Hajduk E., Układy społeczne - przestrzenie procesu socjalizacji, Żary 2008.

Henslin J.M., Social Problems, New Jersey 2003.

Hurrelmann K., Struktura społeczna a rozwój osobowości, Poznań 1994.

Jacher W., Funkcje socjalizacyjne rodziny, Kwartalnik Opolski, 1977, 4.

Jacyno M., Szulżycka A., Dzieciństwo. Doświadczenie bez świata, Warszawa 1999.

Jakowicka M., Uwarunkowania funkcjonowania szkót środowiskowych w średnim mieście, Zielona Góra 1979.

Jasińska-Kania A., Socjologiczna koncepcja osobowości, [w:] Socjologia ogólna. Wykłady dla studentów, red. Z. Krawczyk, W. Morawski, Warszawa 1986.

Jasińska-Kania A. i in. (red.), Wspótczesne teorie socjologiczne, Warszawa 2006.

Jerschina J., Osobowość społeczna studentów Uniwersytetu Jagiellońskiego pochodzenia chtopskiego, Wrocław 1972.

Jędrzejewski S. (red.), Wybór tekstów z socjologii wychowania, Warszawa 1982.

Kaczmarek J., Przestalski A. (red.), Od przeszłości ku nowym horyzontom. W kręgu historii socjologii, Poznań 2013.

Kaleta A. (red.), Józef Chałasiński - socjolog i humanista, Toruń 1984.

Kaźmierska K. (red.), Metoda biograficzna w socjologii, Kraków 2012.

Kłoskowska A., Socjologia młodzieży: przeglad koncepcji, Kultura i Społeczeństwo, 1987, 2.

Kosiński S., Suprewicz J., Wprowadzenie do socjologii wychowania, Lublin 1978.

Kowalik S., Szkic o koncepcjach socjalizacji, [w:] Edukacja wobec zmiany społecznej, red. J. Brzeziński, L. Witkowski, Poznań-Torun 1994.

Kowalski S., Jednostka i jej środowisko społeczne, Wiedza i Życie, 1949, 1.

Kowalski S., Szkoła w środowisku, Warszawa 1969.

Kowalski S., Socjologia a nauki pedagogiczne, Kwartalnik Pedagogiczny, 1969, 3.

Kowalski S., Stan i potrzeby badań nad selekcjami młodzieży na studia wyższe, [w:] Rekrutacja młodzieży na studia wyższe, red. Z. Kietlińska, Warszawa 1973.

Kowalski S., Socjologia wychowania w zarysie, Warszawa 1974.

Kowalski S., Rodzina jako przedmiot socjologii wychowania, [w:] Metodologiczne problemy badań nad rodzina, red. Z. Tyszka, Poznań 1980.

Kowalski S., Systemy oświatowe scentralizowane $i$ zdecentralizowane w świetle wyników badań M.S. Archer, AUNC, Socjologia Wychowania, 1984, 145.

Kowalski S., Uniwersytet Poznański okresu międzywojennego w świetle wspomnień magistranta $i$ doktoranta, Kronika Miasta Poznania, 1990, 1, 1 i 1990, 2, 2.

Kozyr-Kowalski S., Uniwersytet a rynek, Poznań 2005.

Krause-Sikorska H., Klichowski M., Świat digital natives. Młodzież w poszukiwaniu siebie i innych, Poznań 2013.

Krawczyk Z., Sowa K.Z. (red.), Socjologia w Polsce, Rzeszów 1998.

Królikowska J. (red.), Problemy społeczne w grze politycznej, Warszawa 2006. 
Kubiak-Krzywicka W., Interakcyjno-kontekstualny model zaburzonej socjalizacji, PoznańKalisz 2010.

Kukołowicz T., Rodzina w procesie uspołeczniania dziecka, Lublin 1978.

Kurczewska J. (red.), Zmiana społeczna. Teorie i doświadczenia polskie, Warszawa 1999.

Kurowski M.M., Tożsamość socjologii, [w:] Dawne idee nowe problemy, red. P. Śpiewak, Warszawa 2010.

Kurzela J., Kamiński A., Sowa K.S., Z badań nad środowiskiem domu studenckiego, Warszawa 1967.

Kurzępa J., Młodzież pogranicza „świnki”, czyli o prostytucji nieletnich, Kraków 2001.

Kurzępa J., Zagrożona niewinność, Kraków 2007.

Kurzępa J., Młodzi, piękne i niedrodzy. Młodość w objęciach seksbiznesu, Kraków 2012.

Kwaśniewicz W. (red.), Orientacje teoretyczne we wspótczesnej socjologii, Kraków 1990.

Kwaśniewski J. (red.), Badania problemów społecznych, Warszawa 2003.

Kwaśniewski J. (red.), Badania problemów społecznych, cz. 2, Warszawa 2006.

Kwiatkowska G.E., Siudem I. (red.), Zachowania ryzykowne, Lublin. 2012.

Kwiecińska-Zdrenka M., Aktywni czy bezradni wobec własnej przyszłości? Torun 2004.

Kwieciński Z., Funkcjonowanie szkoły w rejonie uprzemystawianym, Warszawa 1972.

Kwieciński Z., Funkcjonowanie szkoły w środowisku wiejskim, Warszawa 1972.

Kwieciński Z., Poziom wiedzy uczniów a środowisko szkoty, Torun 1972.

Kwilecki A., Rola społeczna nauczyciela na Ziemiach Zachodnich, Poznań 1960.

Kwilecki A., Czarnocki B. (red.), The Humanistic Sociology of Florian Znaniecki Polish Period 1920-1939, Warszawa-Poznań 1989.

Leppert R., Melosik Z., Wojtasik B. (red.), Młodzież wobec niegościnnej przyszłości, Wrocław 2005.

Lewicka M., Miasto jako przedmiot badań psychologii, [w:] Miasto jako przedmiot badań naukowych w początkach XXI wieku, red. B. Jałowiecki, Warszawa 2008.

Łaciak B. (red.), Obyczajowość polska początku XXI wieku - w procesie przemian, Warszawa 2014.

Łaciak B., Obyczajowość polska czasu transformacji, Warszawa 2005.

Łoś M., Aspiracje a środowisko, Warszawa 1972.

Maffesoli M., Czas plemion, Warszawa 2008.

Maffesoli M., Rytm życia, Kraków 2012.

Majka J., Wychowanie jako czynność społeczna. Analiza wedtug schematów Znanieckiego i Parsonsa, Roczniki Filozoficzne, 1972, XX, 2.

Malinowski J.A., Zandecki A. (red.), Środowisko, młodzież, zdrowie, Torun 2007.

Mandal E., Stefańska-Klar R. (red.), Wspótczesne problemy socjalizacji, Katowice 1995.

Manterys A., Mucha J. (red.), Nowe perspektywy teorii socjologicznej, Kraków 2009.

Markiewicz W., Wspótczesna mtodzież jako przedmiot badań naukowych, Poznań 1964.

Markiewicz W., Pedagogika a socjologia, Ruch Prawniczy, Ekonomiczny i Socjologiczny, 1974, 4 .

Marody M. (red.), Zmiana czy stagnacja? Warszawa 2004.

Marody M., Formatowanie społeczeństwa - o starych i nowych sposobach uspołeczniania działań, [w:] Co dzieje się ze społeczeństwem, red. M. Flis, K. Frysztacki, G. Skąpska, P. Polak, Kraków 2011.

Marody M., Jednostka po nowoczesności. Perspektywa socjologiczna, Warszawa 2014.

Marody M., Giza-Poleszczuk A., Przemiany więzi społecznych. Zarys teorii zmiany społecznej, Warszawa 2004.

Meier A., Socjologia wychowania, Warszawa 1982. 
Meighan R., Socjologia edukacji, Torun 1993.

Melosik Z. (red.), Młodzież, styl życia i zdrowie. Konteksty i kontrowersje, Poznań 2001.

Melosik Z., Kultura popularna i tożsamość młodzieży, Kraków 2013.

Merton R., Nisbet R., Contemporery Social Problems, New York 1971.

Mielicka H., Socjologia wychowania, Kielce 2000.

Miller R., Socjalizacja, wychowanie, psychoterapia, Warszawa 1982.

Mikulski M., Szkoła środowiskowa w wielkim mieście, Warszawa 1972.

Misztal B., Grupy rówieśnicze młodzieży, Wrocław 1974.

Misztal B., Zagadnienia społecznego uczestnictwa i wspótdziałania, Wrocław 1977.

Miś L., Problemy społeczne. Teoria, metodologia, badania, Kraków 2007.

Miś L., Nóżka M., Smagacz-Poziemska M., Nasze problemy. Bieda i bezrobocie we wspótczesnym społeczeństwie polskim, Kraków 2011.

Modrzewski J., Środowisko społeczne młodzieży studiującej, Poznań 1989.

Modrzewski J., Pedagogika społeczna a socjologia wychowania. Dylematy integracji, [w:] Pedagogika społeczna, tradycja i wspótczesne konteksty, red. W. Theiss, M. Winiarski, Warszawa 2008.

Modrzewski J., Socjalizacja i uczestnictwo społeczne, Poznań 2007.

Modrzewski J., Zandecki A., Młodzież wiejska wśród kandydatów na studia uniwersyteckie, Młodzież i Wieś, 1986, 1.

Moore R., Socjologia edukacji, [w:] Pedagogika, t. 2, red. B. Śliwerski, Gdańsk 2006.

Możdżeńska-Mrozek D., Problemy socjalizacji dorostych. Zagadnienia teoretyczne i metodologiczne, Warszawa 1989.

Niesporek A., Czy koniec socjologii jaka znamy? Katowice 2007.

Nowak S. (red.), Wizje człowieka i społeczeństwa w teoriach i badaniach naukowych, Warszawa 1984.

Nowicka E., Świat człowieka świat kultury, Warszawa 2009.

Olcoń-Kubicka M., Indywidualizacja a nowe formy wspólnotowości, Warszawa 2009.

Osiński J., Uwarunkowania społeczno-przestrzenne selekcji młodzieży do studiów wyższych, Warszawa 1977.

Pańków I., Społeczeństwo a osobowosśc, [w:] Socjologia polska, red. Z. Krawczuk, Warszawa 1990.

Pielka H. (red.), Procesy socjalizacji i wychowania w rodzinie, Koszalin 1990.

Przecławski K., Miasto i wychowanie, Warszawa 1968.

Przecławski K., Instytucje wychowawcze w wielkim mieście. Wybrane problemy z socjologii wychowania, Warszawa 1971.

Radziewicz-Winnicki A. (red.), Pedagogika a socjologia wychowania, Katowice 1986.

Radziewicz-Winnicki A. (red.), Pedagogika a socjologia wychowania. Szkice socjopedagogiczne, Katowice 1989.

Radziewicz-Winnicki A. (red.), Wspótcześni socjologowie o wychowaniu (zarys wybranych koncepcii), Katowice 1993.

Richer S., Socjologia i pedagogika - nowe kierunki badań, Kwartalnik Pedagogiczny, 1987, 4.

Roter A., Proces socjalizacji dzieci w warunkach ubóstwa społecznego, Katowice 2005.

Rybicki P., Struktura społecznego świata, Warszawa 1976.

Rzepa T., Leoński J. (red.), O biografii i metodzie biograficznej, Poznań 1993.

Sadaja B., Społeczne problemy zawodu nauczycielskiego. Nauczyciel - zawód - środowisko, Warszawa 1967.

Sawisz A., System oświaty jako system przemocy symbolicznej w koncepcji Pierre Bourdieu, Studia Socjologiczne, 1978, 2. 
Sawisz A., Krytyka edukacji we wspótczesnej socjologii. Nurty, kontrowersje, propozycje rozwiazań, Kultura i Społeczeństwo, 1988, 1.

Sawisz A., Szkoła a system społeczny, Warszawa 1989.

Schulz R. (red.), Antropologiczne podstawy wychowania, Warszawa 1996.

Segiet K., Dziecko i jego dzieciństwo w perspektywie naukowego poznania $i$ doświadczania rzeczywistości, Poznań 2011.

Sikorska M., Nowa matka, nowy ojciec, nowe dziecko. O nowym układzie sił w polskich rodzinach, Warszawa 2009.

Sipińska D., Modrzewski J., Matysiak-Błaszczyk A. (red.), Socjalizacja w kategoriach wieku społecznego. Standaryzacja socjalizacji inkluzyjnej, t. 1., Leszno 2010, t. 2, Leszno 2011.

Słomczyński K.M., Szkoła $i$ wykształcenie, [w:] Socjologia. Podstawowe problemy, red. Z. Krawczyk, Warszawa 1991.

Smolińska-Theiss B., Dzieciństwo jako status społeczny. Edukacyjne przywileje dzieci klasy średniej, Warszawa 2014.

Sosnowski T., Zakład pracy jako środowisko wychowawcze, Warszawa 1975.

Sowa K.S., Studenci Katowic i Krakowa, Warszawa 1971.

Suchocka R. (red.), Wspótczesne społeczeństwo polskie, Poznań 2002.

Suszek K., Środowiskowe uwarunkowania procesu uspołecznienia studentów, Szczecin 1967.

Szacka B. (red.), Polska dziecięca, Warszawa 1987.

Szafraniec K. (red.), Młodzi 2011, Warszawa 2011.

Szczepański J., O pojęciu środowiska, Przegląd Socjologiczny, 1946, 1-4.

Szczepański J., Przejście z rodziny do szkoty w życiorysach młodzieży, Przegląd Socjologiczny, 1935, 1-2.

Szczepański J., recenzja podręcznika J. Simy, Sociologie vychovy, Praga 1938, Przegląd Socjologiczny, 1946, 1-4.

Szczepański J., Socjologiczne zagadnienia wyższego wykształcenia, Warszawa 1963.

Szczepański J., Rzecz o nauczycielach w wychowującym społeczeństwie socjalistycznym, Warszawa 1974.

Szczepański J., Dzienniki z lat 1935 - 1945, Ustroń 2009.

Szlendak T., Socjologia rodziny. Ewolucja, historia, zróżnicowanie, Warszawa 2010.

Szmatka J., Socjologia wychowania - zarys problematyki, Psychologia Wychowawcza, 1972, 3.

Szmatka J., Jednostka $i$ społeczeństwo. O zależności zjawisk indywidualnych od społecznych, Warszawa 1980.

Szmatka J., Struktura rzeczywistości społecznej, rozwój społeczny - wychowanie, Studia Socjologiczne, 1980, 4.

Sztumski J., Problem społeczny jako przedmiot badań, Studia Socjologiczne, 1977, 3.

Szymański M.J., Środowiskowe uwarunkowania selekcji szkolnej, Warszawa 1973.

Szymański M.J., Selekcyjne funkcje szkolnictwa a struktura społeczna, Warszawa 1996.

Theiss W., Winiarski M., Pedagogika społeczna, tradycja i wspótczesne konteksty, Warszawa 2008.

Tillmann K.J., Teorie socjalizacji, Warszawa 1996, wyd. II, Warszawa 2005.

Toporkiewicz R., Socjologia wychowania, Warszawa 1986.

Touraine A., O socjologii, Warszawa 2010.

Turner B.S. (red.), The New Blackwell Companion to Social Theory, Oxford-ChichesterMalden 2009.

Urry J., Socjologia mobilności, Warszawa 2009.

Uziembło A.O., Pedagogika społeczna $i$ jej zwiazek z socjologia wychowania, Studia Socjologiczne, 19664. 
Wasilewski J. (red.), Wybrane zagadnienia metodologiczno-teoretyczne badań socjologicznych, Kraków 1984.

Wawryniuk S., Ksztattowanie się systemu wychowawczego w wielkomiejskim osiedlu mieszkaniowym, Poznań 1976.

Wesołowski W., Włodarek J. (red.), Kręgi integracji i rodzaje tożsamości. Polska, Europa, Świat, Warszawa 2005.

Wieviorka M., Dziewięć wykładów z socjologii, Kraków 2011.

Wincławski W., Przemiany środowiska wychowawczego wsi w rejonie uprzemystawianym. Studium porównawcze 20 wsi gromady Bielsk w powiecie płockim, Warszawa 1973.

Wincławski W., Typowe środowiska wychowawcze współczesnej Polski, Warszawa 1976.

Wincławski W., Rozwój polskiej socjologii wychowania w świetle recepcji Znanieckiego w okresie Drugiej Rzeczypospolitej, Kultura i Społeczeństwo, 1977, 3.

Wincławski W., U źródet refleksji socjologicznej nad wychowaniem w Polsce, AUNC, Socjologia Wychowania, 1984, V, 145.

Wiśniewski W. (red.), Oświata w społecznej świadomości, Warszawa 1984.

Włodarek J., Socjologia wychowania w Polsce, Poznań 1992.

Włodarek J., Tradycje badawcze i perspektywy rozwoju socjologii w Uniwersytecie Poznańskim, [w:] Między przeszłością a przyszłością, red. J. Włodarek, Poznań 1998.

Włodarek J. (red.), Między przeszłością a przyszłością, Poznań 1998.

Włodarek J., Ziółkowski M. (red.), Metoda biograficzna w socjologii, Warszawa-Poznań 1990.

Woskowski J., O pozycji społecznej nauczyciela, Łódź-Warszawa 1964.

Woskowski J., Socjologia wychowania, Warszawa 1983.

Woskowski J. (red.), Z socjologicznej problematyki oświaty, wychowania i młodzieży, Łódź 1981.

Woźniak R.B., Zarys socjologii edukacji i zachowań społecznych, Koszalin 1997.

Zalewska J., Cobel-Tokarska M. (red.), Od obyczaju do mody. Przemiany życia codziennego, Warszawa 2014.

Zemło M., Nowa socjologia edukacji, Białystok 1996.

Zieliński J., Młodzież chłopska na studiach, Warszawa 1982.

Znaniecki F., The Scientific Function of the Sociology of Education, Educational Theory, 1951, 2.

Zychowicz I.A., Studenci Koszalina - edukacja i socjalizacja, Koszalin 2014.

Żuk P., O nierównościach edukacyjnych w Polsce, [w:] Podziały klasowe i nierówności społeczne, red. P. Żuk, Warszawa 2010.

Żuk P. (red.), Podziały klasowe i nierówności społeczne, Warszawa 2010. 